\title{
BRICS ve MINT Ülkelerinde Dış Borç ile Büyüme Arasındaki İlişkinin Değerlendirilmesi (2000-2018)
}

\author{
Evaluation of the Relationship between External Debt and Growth in BRICS and MINT Countries \\ (2000-2018)
}

\author{
Özlem Ülger Danac1*
}

\begin{abstract}
Borrowing from economies with excess funds to countries with fund deficits other than their own currency is defined as external debt. External borrowing is especially used for reasons such as foreign trade and budget deficit financing, defense spending financing, debt cycle and extraordinary spending. States prefer to use tax revenues primarily in financing public expenditures. However, the fact that the revenues generated through taxes are not sufficient to finance public deficits led states to turn to sources such as domestic and foreign borrowing. Economic approaches provide different perspectives on the impact of external borrowing on economic growth. In this context, economic growth is defined as the increase in the amount of goods and services produced in a country's economy in a certain period. In addition, the effects of external borrowing, which are used extensively in developing countries, on the economy should be analyzed well. While analyzing foreign borrowing, it is important to examine especially the exports and imports of countries. In this direction, firstly, export and import values of BRICS and MINT countries belonging to 2000-2018 period are presented through tables and graphs. In addition, foreign debt and growth data of 2000-2018 were analyzed and countries were examined separately. When the graphs and tables are analyzed, it is concluded that growth is generally at low levels in periods of high external debt, and growth at high levels in periods of low external debt.
\end{abstract}

Structered Abstract: External borrowing is among the important problems especially for developing countries. With the insufficient domestic savings, the lack of necessary investments and low export revenues, the need for foreign debt of countries with foreign exchange difficulties increases. Borrowing from economies with excess funds to countries with fund deficits other than their own currency is defined as external debt. External borrowing is mainly used for reasons such as foreign trade and budget deficit financing, defense spending financing, debt cycle and extraordinary spending. States first started using tax revenues in financing public spending. However, the fact that the revenues obtained through taxes were not sufficient to finance public deficits led states to turn to sources such as domestic and foreign borrowing.

Economic approaches provide different perspectives on the impact of external borrowing on economic growth. The first of these approaches is the classical growth theory and according to this theory, the investments are the source of economic growth, and these investments cause an increase in the productivity of the land while increasing the productivity of the land. Secondly, according to Keynes, the disruptions in the growth

\footnotetext{
* Dr. Öğrt. Üyesi, Batman Üniversitesi, İktisadi ve İdari Bilimler Fakültesi, İktisat Bölümü Asst. Prof. Dr., Batman University, Faculty of Economics and Administrative Sciences Department of Economics ORCID 0000-0002-3872-3330

oulger06@hotmail.com

Cite as/ Atıf: Ülger Danacı, Ö. (2020). BRICS ve MINT ülkelerinde dıș borç ile büyüme arasındaki ilișkinin değerlendirilmesi (2000-2018). Turkish Studies - Economy, 15(3), 1675-1696. https://dx.doi.org/10.47644/TurkishStudies.42743

Received/Geliş: 03 April/Nisan 2020

Accepted/Kabul: 20 September/Eylül 2020

Copyright $($ INTAC LTD, Turkey

Checked by plagiarism software Published/Yayın: 25 September/Eylül 2020 CC BY-NC 4.0
} 
processes of developing countries cause foreign debt to contribute significantly on economic growth. The debt growth relationship that started with Keynes then continues with the Harrod Domar model. According to the model, the most basic relationship between savings and economic growth rate is shown, and capital accumulation as savings is required to achieve growth. In 1966-1979, Chenery and Strout developed the "twin open approach" model by developing the Harrod-Domar model. According to the model, developing countries face savings deficit and trade deficit therefore, foreign resource inflows and foreign capital inflows in countries are important in closing the gap. According to neoclassical economists, the external debt burden comes to the fore as tax in the future. In the theory of debt overhang proposed by Krugman, it is argued that if a country has a discounted value of resource transfers in the future and the current value of its debts is lower than the debt problem in that country. Another theory that addresses the basic framework of the external debt growth relationship is debt growth theory and is discussed in terms of the benefits and costs of borrowing in the process of economic growth. Another theory that addresses the basic framework of the external debt growth relationship is the growth-cum debt theory and the benefits and costs of borrowing in the economic growth process. Finally, in the intertemporal borrowing model, it argues that a country with high debt has a high discount rate or low intertemporal substitution flexibility and the importance of international borrowing in closing the savings gap in the country.

In this direction, firstly, export and import values of BRICS and MINT countries belonging to 20002018 period are presented through tables and graphs. In addition, foreign debt and growth data of 2000-2018 were analyzed and countries were examined separately.

In 2001, Jim O'Neill, Head of Asset Management of Goldman Sachs Bank, the international investment bank, published a report using the term "BRIC" to describe the world's largest emerging markets. BRIC; It is a term consisting of the initials of Brazil, Russia, India and People's Republic of China. The Republic of South Africa joined the BRIC community in 2010 and the term was updated as BRICS. In the evaluation of BRICS countries as a different economic group, Russia has a commodity-driven economy, China has an export-oriented economy, India has a consumer originated economy, Brazil's substantial economic development and South Africa's rapidly growing region plays an important role.

When the BRICS countries are analyzed, it is possible to observe that it was seriously affected by the 2008 global financial crisis. However, when the growth data are analyzed since 2000s, it can be said that their economies are growing rapidly and they have the power to affect the global economy. Accordingly, Brazil entered the recessionist period with the emergence of corruption in the government in 2013 and the increase in transportation fees, and the negative process in the economy continued with the depreciation of the national currency Real in 2016. It is possible to say that the Brazilian economy recovered in 2017 due to the increase in commodity prices and the recovery in domestic demand. Due to the geopolitical problems experienced in 2014 in Russia and the drop in oil prices, the economy experienced negative problems and this situation lasted almost 3 years. It is possible to say that there was a recovery in the Russian economy with the increase in foreign global demand in 2017. India, which is preparing to come to the fore as the rival of China in the following period, entered a slow growth process in 2016 by making decisions regarding the withdrawal of 500 and 1000 rupees banknotes from the market and making tax regulations in 2017. The low growth rate of China, which is the 2nd biggest economy of the world, which was at 7\% in 2012, was named as "new normal" and continued at these levels. Due to trade wars and high debts with the USA in 2018, it has maintained its lowest growth level in the last 29 years. Finally, South Africa is among the biggest trading partners of China. The devaluations, decreases in commodity prices and problems in debt sustainability affected negatively in 2015. In general, it is observed that as the foreign debts of the countries increase, their growth decreases. The corona virus, which emerged in Wuhan city of China in 2020, has seriously affected the countries and it is expected that this will be reflected in foreign trade, foreign debts and growth rates.

Four groups of countries, namely Mexico, Indonesia, Nigeria and MINT acronym referring to Turkey, it was first created in 2014 by Fidelity Investments, a Boston-based asset management company. It can be said that when O'Neill put forward the BRICS term, did not include in this group, but there were also countries that evaluated in this context. Mexico, Indonesia, Nigeria and Turkey covering these countries since the beginning of 2014 has been characterized as "emerging giants". MINT countries, whose economic prospects for the future are bright, are a group of countries operating as an economic power following BRICS countries. One of the common features of MINT countries is that it has a fast growing young and dynamic labor resource.

Turkish Studies - Economy, 15(3) 
Like BRICS countries, MINT countries have been severely affected by the 2008 crisis. With the 2008 crisis in Mexico, the H1N1 epidemic and drug cartels in the country has entered the recessionist process in 2009. Along with the decrease in foreign demand and public expenditures, the level of economic growth remained at $2 \%$. Indonesia, which experienced the lowest growth rate with the declines in exports in 2012 after the global financial crisis, was affected by commercial wars between the USA and China in 2018. Nigeria, which provided $90 \%$ of its exports through crude oil, entered the recession process in 2016, along with the decline in foreign exchange revenues and problems in financing imports. On the other hand, in 2018, there was an increase in growth along with positive progress such as the increase in oil prices and increases in service and industrial production. Finally, Turkey is located in the MINT group is said to fluctuations in growth rates. The liquidity crisis in 2001 and the mortgage crises in the USA in 2008 negatively affected the growth level of the country. The visa crisis with the US in 2016 and the Priest Brunson incident were also reflected in the country's growth rates. When the external debt and growth relationship of the countries included in the MINT group is examined, it is observed that there is a reverse relationship. The MINT group is expected to be severely affected by the corona virus, which affects the entire world, like the BRICS countries. Although reform packages are implemented in this process, countries are expected to have a negative impact on many macroeconomic indicators such as growth, exports, imports and external debts.

As a result, BRICS and MINT countries should use their debts in productive investments to increase the production, increase national income and ensure the development of the country. If these are provided, it is likely that countries will develop and a decrease in foreign debt in the long term may increase in domestic savings.

Keywords: BRICS, MINT, Foreign Debt, Economic Growth, External Debt

Jel Code: F43, F32, H68

Öz: Fon fazlası olan ekonomilerden fon açığı olan ülkelere yönelik kendi para birimi dışında yapılan borçlanmalar dış borç olarak tanımlanmaktadır. Dış borçlanma özellikle dış ticaret ve bütçe açığının giderilmesi, savunma harcamalarının finansmanının sağlanması, borçların çevrimi ve olağanüstü harcamaların karşılanması gibi nedenlerle kullanılmaktadır. Kamu harcamalarının finanse edilmesinde devletler öncelikli olarak vergi gelirlerini kullanmayı tercih etmektedirler. Fakat vergi aracıllğıyla elde edilen gelirlerin kamu açıklarını finanse etmede yeterli olmaması devletleri, iç ve dış borçlanma gibi kaynaklara yönelmesine yol açmışır. Dış borçlanmanın ekonomik büyüme üzerindeki etkisi hakkında konu ile ilgili olarak iktisadi yaklaşımlar farklı bakış açıları sunmaktadır. Bu kapsamda ekonomik büyüme ise, bir ülke ekonomisinde belirli bir dönemde üretilen mal ve hizmetlerin miktarında meydana gelen artış olarak tanımlanmaktadır. Bununla birlikte özellikle gelişmekte olan ülkelerde yoğun bir şekilde kullanılan dış borçlanmaların ekonomi üzerinde oluşturacağ etkiler iyi analiz edilmelidir. Dış borçlanma analiz edilirken ülkelerin özellikle ihracat ve ithalatlarının incelenmesi önemli olmaktadır. Bu doğrultuda çalışmada öncelikle 2000-2018 dönemine ait BRICS ve MINT ülkelerinin ihracat ve ithalat değerleri tablo ve grafikler aracılı̆gıla sunulmuştur. Beraberinde ise 2000-2018 yıllarına ait dış borç ve büyüme verileri ele alınarak ülkeler ayrı ayrı incelenmiştir. Grafikler ve tablolar incelendiğinde genel olarak dış borcun yüksek olduğu dönemlerde büyümenin düşük seviyelerde, dış borcun düşük olduğu dönemlerde ise büyümenin yüksek düzeylerde gerçekleştiği sonucuna ulaşılmıştır.

Anahtar Kelimeler: BRICS, MINT, Dış Borç, Ekonomik Büyüme, Dış Ticaret

Jel Kodu: F43, F32, H68

\section{Giriş}

Dış borçlanma özellikle gelişmekte olan ülkeler açısından önemli sorunlar arasında yer alır. İç tasarrufların yetersiz olması, gerekli yatırımların yapılamaması ve ihracat gelirlerin düşük olmasıyla birlikte döviz sıkıntısı yaşayan ülkelerin dış borca olan gereksinimi artmaktadır. Dış borçlanma, ülkelerin kaynaklarına ek bir kaynak sağlamak ve döviz cinsinden yeni ödeme gücü elde etmek amacıyla ülke dışında yerleşik olan hükümet veya finans kuruluşlarından ya karşılıksız olarak ya da karşılıklı olarak geri ödemeli veya geri ödemesiz alınan kaynak olarak tanımlanmaktadır. Dış 
borçlanma ile elde edilen kaynakların maliyetleri gelirlerinden fazla olması durumunda yurt dışına negatif sermaye transferine ve yurt içinde yer alan kaynaklara olan ihtiyaçların artmasına neden olur.

Dış borçlanmanın ekonomik büyüme üzerine etkisi ile ilgili olarak iktisadi yaklaşımların farklı bakış açıları söz konusudur. Bu yaklaşımlardan ilki Klasik büyüme teorisidir ve bu teoriye göre ekonomik büyümenin kaynağını yatırımlar oluşturmakta ve söz konusu yatırımlar bir yandan işgücü verimliliğginde artışa neden olurken, diğer yandan da yatırımlarla beraber tarımsal üretimde verimlilik artışına yol açmaktadır. İkinci olarak Keynes'e göre, gelişmekte olan ülkelerin büyüme süreçlerinde meydana gelen aksaklıklar, dış borcun ekonomik büyüme üzerinde önemli bir katkısı vardır. Keynes ile başlayan borç büyüme iliş̧kisi daha sonra Harrod Domar modeli ile devam etmektedir. Modele göre, tasarruflar ile ekonomik büyüme oranı arasındaki en temel ilişki gösterilmekte ve büyümenin gerçekleşmesi için tasarruf olarak sermaye birikimine ihtiyaç duyulmaktadır.1966-1979 yıllarında Chenery ve Strout, Harrod-Domar modelini geliştirerek "ikiz açık yaklaşımı" modelini öne sürmüşlerdir. Modele göre gelişmekte olan ülkeler tasarruf açığ 1 ve ticaret açığı ile karşı karşıya kalmakta dolayısıyla ülkelerdeki dış kaynak girişleri ve yabancı sermaye girişleri söz konusu açığı kapatmada önemli olmaktadır. Neoklasik iktisatçılara göre ise diş borç yükü, gelecekte vergi olarak ön plana çıkmaktadır. Krugman tarafindan ortaya atılan borç fazlası teorisinde ise, bir ülkenin gelecekte kaynak transferlerinin iskonto edilmiş değeri, borçlarının mevcut değerinden düşük düzeyde ise söz konusu ülkede borç sorununun olduğu savunulmuştur. D1ş borç büyüme ilişskisinin temel çerçevesini ele alan diğer teori ise, borçla büyüme teorisidir ve ekonomik büyüme sürecinde borçlanmanın faydaları ve maliyetleri açısından ele alınmışıır. Son olarak zamanlararası borçlanma modelinde ise, yüksek düzeylerde borcu olan bir ülkenin, yüksek iskonto oranı ya da zamanlararası ikame esnekliğinin düşük olduğu savunulmakta ve uluslararası borçlanmanın ülkede mevcut olan tasarruf açığııı kapatmadaki önemi gösterilmektedir.

Çalışmada BRICS ve MINT ülkelerinin dış borç ile büyüme arasındaki ilişki 2000-2018 dönemi verileri kullanılarak incelenmeye çalışılmıştır. Bu kapsamda ilk olarak dış borçlanmanın kavramsal çerçevesi ve ekonomik büyüme ile ilişkisini açıklayan teoriler incelenmiştir. İkinci olarak ise BRICS ülkelerinin dış borç ve büyüme ilişkisi, son olarak ise MINT ülkelerinin diş borç ve büyüme ilişkisi incelenmiştir.

1. Dış Borçlanmanın Kavramsal Çerçevesi ve Ekonomik Büyüme ile İliş̧kisini Açıklayan Teoriler

Dış borçlanma, gelişmekte olan ülkeler açısından önemli sorunlar arasında yer almaktadır. İç tasarrufların yetersiz olması, ihtiyaç duyulan yatırımların yapılamaması, ihracat gelirlerinin düşük olması ve dolayısıyla dövizde yaşanan sıkıntılar bu ülkelerin dış borca olan gereksinimini ortaya çıkarmıştır (Kamacı, 2016:167). Kamu harcamalarının finanse edilmesinde devletler ilk olarak vergi gelirlerini kullanmaya başlamıştır. Fakat vergi aracılığıyla elde edilen gelirlerin kamu açıklarını finanse etmede yeterli olmaması devletlerin, iç ve dış borçlanma gibi kaynaklara yönelmesine yol açmıştır (Eser \& Birinci, 2014: 31). Ayrıca dış ticarette ve bütçede meydana gelen açıkların giderilmesi, savunma harcamalarının finanse edilmesi, borçların çevrimi ve olağanüstü durumlarda meydana gelen harcamaların karşılanması gibi nedenlerle de dış borçlanmadan faydalanılabilmektedir (Uysal, Özer \& Mucuk, 2009:161).

Uluslararası Ödemeler Bankası (BIS), Dünya Bankası (World Bank), Uluslararası Para Fonu (IMF) ve Ekonomik İşbirliği ve Kalkınma Örgütü (OECD) gibi grupların yer aldığı Dış Borç İstatistikleri Çalışma Grubu tarafından 1988 yılında dış borcun genel bir tanımı yapılmıştır. Buna göre, herhangi bir zamanda, bir ülkede ikamet eden kişi ve kuruluşların başka bir ülkede ikamet eden kişi ve kuruluşlara sözleşme kapsamında sorumlu oldukları anaparalarını faizli veya faizsiz olarak geri ödemelerinin veya anaparalı ya da anaparasız faiz ödemelerinin miktarına bürüt dış borç denir. Brüt borç, borç servisinin hesaplandığı borç stokudur (Klein,1994: 56). 
Devletin veya bir kamu kuruluşunun dış kaynaklar aracılığıyla gelir elde etmesi olarak nitelendirilen dış borçlanma, özellikle gelişmekte olan ülkelerde iktisadi kalkınma süreçlerini sürdürebilmeleri için yoğun bir şekilde kullanılmaktadır (Bilginoğlu \& Aysu, 2008:2). Bu ülkelerde iktisadi büyümenin hızını arttırabilmek için iç tasarrufların arttırılması gereklidir. Fakat iç tasarrufları yeterli olmayan gelişmekte olan ülkeler genellikle dış borca ihtiyaç duymaktadır (Gül, Kamacı \& Konya, 2012:169). Dış borç ile iç borç arasındaki en önemli farklardan biri, dış borç alan ülkeye kaynak transferinin sağlanması ile birlikte milli gelirin artmasıdır. Alınan dış borçların geri ödenmesinde anapara ve faiz ödemeleri yapıldığ neden olmaktadır. Dış borçlanma ile elde edilen kaynakların maliyetleri gelirlerinden fazla olması durumunda yurt dışına negatif sermaye transferine yol açar; bu da yurt içinde yer alan kaynaklara olan ihtiyaçların artmasına neden olur. Ekonomik büyümenin sağlanması için gelişmekte olan ülkeler ihtiyaç duydukları yatırım mallarını ithalat yoluyla karşılamaktadırlar. Fakat ülkelerin ithalatlarını karşılamaya yardımcı olan ihracat gelirleri düşük olduğu için döviz darboğazı ile karşı karşıya kalması durumunda dış borçlara olan ihtiyacı artırmaktadır (Çöğürcü \& Çoban, 2011: 133-134).

Dış borçlanmanın ekonomik büyüme üzerine etkisi ile ilgi konu hakkında iktisadi yaklaşımlar farklı bakış açıları sunmaktadır. Bu yaklaşımlardan ilk olarak klasik büyüme modeline göre, ekonomik büyümenin kaynağını yatırımlar oluşturmakta ve söz konusu yatırımlar bir yandan işgücü verimliliğinde artışa neden olurken, diğer yandan da toprağın verimini arttırarak üretimin yükselmesine yol açmaktadır. Kar oranları yatırımların artmasında temel faktördür ve kar oranı ne kadar yükssek düzeylerde gerçekleşirse yatırımlarda buna bağlı olarak artış göstermektedir. Klasik modele göre nüfusta meydana gelen artış toplam gelir içinde ücretin ve rantın payını yükseltirken kardan elde edilen payın giderek azalmasına ve bununla birlikte yatırımların durmasına ve böylece sistemin durgunluğa girmesine yol açmaktadır (Uysal, Özer \& Mucuk, 2009:161).

Dış borç ve ekonomik büyüme arasındaki ilişki Keynes'in genel teorisinde, ekonomik büyümede artışın sağlanabilmesi için devlet müdahalesinin gerekli olduğu savunulmuştur. Keynes'e göre gelişmekte olan ülkelerin büyüme süreçlerinde meydana gelen aksaklıklar, diş borcun ekonomik büyüme üzerinde önemli katkılar sağlamasına yol açmaktadır (Erataş \& Nur, 2013:209-210). Keynes ile başlayan borç büyüme ilişkisi daha sonra Harrod Domar modeli ile devam etmektedir. HarrodDomar büyüme modeli, tasarruflar ile ekonomik büyüme oranı arasındaki en temel ilişkiyi göstermektedir. Modele göre, büyümenin gerçekleşmesi için tasarruf olarak sermaye birikimi gerekli olmaktadır. Dolayısıyla dış borçlanma, gelişmenin sağlanabilmesi için gelişmekte olan ülkelerdeki finansman açığının kapatılmasına yardımcı olabilecek bir sermaye olarak görülmektedir (Senadza, Fiagbe \& Quartey, 2017:63). Kisaca Harrod-Domar modelinde üretim, yatırım oranına ve bu yatırımın verimliliğine bağlıdır. Yatırımlar, tasarrufla finanse edilirse açık bir ekonomide toplam tasarruf iç ve dış tasarrufların toplamına eşit olur. Yurtiçi tasarrufların, hedeflenen büyüme oranına ulaşabilmesi için gereken yatırımın yetersiz olması durumunda bir tasarruf açığı ortaya çıkmaktadır. Tasarruf düzeyinin düşük olması durumunda ise dış borç almak, doğrudan ve dolaylı etkileriyle yatırımların artmasını sağlamakta ve böylece yüksek büyüme ve gelir elde edilmektedir (Hjertholm, Laursen, \& White, 1998:3-4).

Gelişmekte olan ülkelerde ekonomik büyümenin önündeki en önemli engel, yatırım için gerekli olan tasarruf eksikliğidir. 1966-1979 yıllarında Chenery ve Strout, Harrod-Domar modelini geliştirerek "ikiz açık yaklaşımı" modelini ortaya atmışlardır. Buna göre gelişmekte olan ülkeler tasarruf açığı ve ticaret açığı ile karşı karşıya kalmaktadır. Dolayısıyla ülkelerdeki dış kaynak girişleri ve yabancı sermaye girişleri söz konusu açı̆̆ı kapatmada önemli olmaktadır. Eğer söz konusu bu girişler sağlanamazsa ülkelerin daha yavaş büyümesi ve iç kaynakların (işgücü ve doğal kaynaklar) verimsiz olması durumu ortaya çıkmaktadır. İkiz açık modeline göre alınan dış borçlar, yatırım ve tasarrufu artırmakta ve bu durum ekonomik büyümeye yol açmaktadır (Moreira, 2005: 27). 
Dış borcun ülke ekonomisine yönelik etkisi ile ilgili birçok çalışma yapılmış ve dış borcun ekonomik büyümeyi hızlandırdığı sonucuna ulaşılmıştır. Söz konusu bu sonuç neoklasik ekonomik büyüme modeli ile uyumludur. Fakat bu yaklaşım gerçekçi olmayan tam sermaye hareketliliği varsayımı nedeniyle eksik kalmaktadır (Nwannebuike, Ike \& Onuka, 2016:36). Neoklasik iktisatçılara göre dış borç yükü, gelecekte vergi olarak ön plana çıkmaktadır. Dolayısıyla bu dış borç ve büyüme arasında negatif bir ilişki söz konusu olmaktadır (Diallo, 2009:223). Yani, dış borçlara yapılan faiz ödemelerinin gerçekleştirilebilmesi için vergi uygulanmasının yapılması, bireylerin harcanabilir gelirini azaltır ve böylece vergi mükellefinin tasarruflarında bir düşüşe yol açar (Senadza, Fiagbe \& Quartey, 2017:63).

Dış borç stoku ve ekonomik büyüme arasında yer alan temel teori "borç fazlası" teorisidir (Krugman, 1988). Borç fazlası (debt overhang) teorisine göre, eğer borç stoku ülkenin gelecekte geri ödeme olasılı̆̆ında düşüşe yol açarsa, dış kredilerin ekonomik büyüme üzerinde olumsuz etkilere neden olacaktır (Diallo, 2009:223). Krugman tarafindan ortaya atılan borç fazlası modelinde, bir ülkenin gelecekte kaynak transferlerinin iskonto edilmiş değeri, borçlarının mevcut değerinden düşük düzeyde ise söz konusu ülkede borç sorununun olduğu savunulmaktadır. Borç fazlasının sürekli hale geldiği ülkelerde, mevcut dönemde ve gelecek dönemlerde hem yerli girişimciler hem de yabancı girişimciler tarafından daha düşük düzeylerde yatırım söz konudur. Bununla birlikte devletin uygulamış olduğu deflasyonist ya da enflasyonist politika uygulamaları yatırımcılar açısından caydırıcı özellik taşır. Dolayısıyla dış borçlarda meydana gelen aşırı artışlar yatırımlarda olumsuz etkilere yol açarak ekonomik büyümenin de düşük düzeylerde gerçekleşmesine neden olur (Zhumakunova \& Kydyralieva, 2017: 368).

D1ş borç büyüme ilişkisinin temel çerçevesini ele alan diğer teori, borçla büyüme (GrowthCum Debt) teorisidir. Bu teoride borç servisi kapasitesi, ekonomik büyüme sürecinde borçlanmanın faydaları ve maliyetleri açısından ele alınmaktadır (Sesan, 2013). Bir ülke sadece yatırımın bir kısmını finanse etmek için değil, aynı zamanda amortisman paylarını karşılamak ve bu süreçte biriken borçlar için de faiz ödemek zorundadır. Daha önce tahakkuk eden borç faizleri, faiz de içeren yeni borçlanma ile ödenmekte ve dış kaynakların maliyetini yansıtmaktadır. Bununla birlikte dış kaynakların faydası ise elde edilen gelirin bir kısmı tasarruf için kullanılırsa ülke zaman içinde yatırım ihtiyacını kendi iç kaynaklarından karşılamasıyla ortaya çıkar (Avramovic, at all. 1964:53). Dolayısıyla borç kapasitesinin sürdürülebilir olabilmesi için ek dış borçların, zamanla iktisadi kalkınmaya yeterli düzeyde katkı yapması gerekmektedir.

Dış borçlanma ve ekonomik büyüme arasındaki ilişkiyi açıklayan son model ise zamanlararası borçlanma (intertemporal borrowing) modelidir. Bu model, yüksek düzeylerde borcu olan bir ülkenin, yüksek iskonto oranı ya da zamanlararası ikame esnekliğinin düşük olduğunu savunmaktadır. Zamanlararası borçlanma modeli, uluslararası borçlanmanın ülkede mevcut olan tasarruf açı̆̆ını kapatmadaki önemini göstermektedir (Nissanke \&Ferrarini, 2001:1). Dış borçlanmanın faydaları arasında, "zamanlararası borçlanma/borç verme" modeline uyarlanan zamanlararası yatırım-tüketim modeli gösterilebilir. Modele göre bir ülkenin borçlanması, şimdiki ve gelecekteki yatırım ile birlikte tüketimi artırma ve gelecekteki büyümeyi teşvik etme imkânı sağladığını göstermektedir (Ossemane, 2007:3). Söz konusu modelde, zamanlararası tüketim ya da borçlanma ile özellikle gelişmekte olan ülkelerde yer alan tasarruf açığının kapatılabileceği üzerinde durulmaktadır. Bu ülkelerde iktisadi büyüme hedeflenen seviyede gerçekleşmiyorsa kamu gelirlerini artırabilmek için dış kaynaklara başvurulmaktadır. Böylelikle cari dönemde gelir düzeyi artar ve büyümeye engel olan nedenler ortadan kalkmış olur (Zhumakunova \& Kydyralieva, 2017: 368).

\section{2. $\quad$ BRICS Ülkelerinde Dış Borç ve Büyüme Arasındaki İlişki}

Uluslararası yatırım bankası olan Goldman Sachs Bank'ın Varlık Yönetim Başkanı Jim O'Neill 2001 yılında, dünyanın en büyük gelişmekte olan pazarlarını tanımlamak için "BRIC" terimini kullandığı bir rapor yayınlamıştır (O’Neill, 2001: 4-11). BRIC ülkeleri, dört BRIC ülkenin 
her birinin ilk harflerinden oluşan bir kısaltmadan yani Brezilya, Rusya Federasyonu, Hindistan ve Çin Halk Cumhuriyeti'nin baş harflerinden oluşan bir terimdir (Stefansson, 2010: 6). BRIC bu dört ülkenin baş harflerinin sıralanması ile ortaya çıkmış bir kavramdır. Burada aynı zamanda İngilizcedeki "brick"(tuğla) kelimesine de bir gönderme yapıldığı görülmektedir. Bu oluşum ile yeni bir ekonomik blok kurulacak ve küresel ekonomik güç G-7 ülkelerinden giderek gelişmekte olan ülkelere kayacaktır (ATAUM, 2017).

2009 y1lında Rusya'da gerçekleştirilen ilk BRIC ülkeleri zirvesinde yaşanmakta olan küresel ekonomik krizden gıda ve enerji güvenliğine, iklim değişiminden uluslararası finansal kurumlarda reforma kadar değişik konular ele alınmıştır. 2010 yılında topluluğa Güney Afrika Cumhuriyeti de katılmış ve bundan sonra BRICS adıyla anılmaya başlanmıştır. Takip eden yıllık zirvelerde küresel finans sisteminde yeniden yapılanma ve BRICS ülkelerinin bu kapsamdaki rolü, yeni bir kalkınma bankası kurulması gibi üye ülkelerin küresel ekonomik düzendeki ağırlığını artırıcı görüşler ve deklarasyonlar yayımlanmıştır (Oğuz, 2018: 444-445). BRICS ülkeleri şu anda, işbirliği alanlarını önemli ölçüde genişletmiş, derinleştirmiş, deklarasyonlardan ve programlardan gerçek eyleme geçmiştir (Gladun, 2018).

BRICS ülkelerinin farklı bir ekonomik grup olarak değerlendirilmesinde, Rusya'nın meta güdümlü bir ekonomisinin olması, Çin'in ihracat odaklı ekonomisinin olması, Hindistan'ın tüketici kaynaklı bir ekonomisinin olması, Brezilya'nın ekonomik yapıyı önemli düzeyde geliştirmesi ve Güney Afrika'nın hızla büyüyen bölgeyi temsil etmesi önemli rol oynamaktadır (Jash, 2017: 3). BRICS ülkeleri, küresel nüfusun \%43'ünü oluşturmakta ve dünya kara kütlesinin yaklaşı \%30'unu kapsamaktadır. Siyasi farklılıklarına rağmen bu beş ülke küresel ekonomiye entegre bir ekonomik yapıyı benimsemiştir (Thussu, 2015). Yüksek büyüme oranlarının, ekonomik potansiyelin ve demografik gelişmenin BRICS'i daha da ileriye taşıyacağı ve artan ilgi düzeylerinin de G7'ye dahil edileceği belirtilmiştir (Mrozan, et all., 2012).

Uluslararası forum ve kuruluşlar BRICS ülkelerinin ekonomik, finansal ve politik yönetişim alanlarına odaklanmaktadır. Ekonomik ve finansal kapsamda BRICS gündemi, IMF reformu da dâhil olmak üzere G-20 ile işbirliğini ön plana almaktadır. Politik kapsamda BRICS gündemi ise Birleşmiş Milletler ve Güvenlik Konseyi'nin daha kapsamlı bir temsil ve daha demokratik bir uluslararası yönetime yönelik reformu savunmaktadır. Ayrıca, BRICS uluslararası gündemde yer alan ana konular üzerinde de sürekli bir diyalog sürdürmüş ve tarım, bilim ve teknoloji, kültür, düşünce kuruluşları, internet yönetişimi ve güvenliği, sosyal refah, fikri mülkiyet, sağlık ve turizm gibi alanlarda da gelişme göstermiştir (Jash, 2017: 3). 
Tablo 1: BRICS Ülkelerinin 2000-2019 Dönemleri D1ş Ticaret Verileri (Current ABD \$)

\begin{tabular}{|c|c|c|c|c|c|c|}
\hline & & Brezilya & Rusya & Hindistan & Çin & Güney Afrika \\
\hline \multirow[t]{2}{*}{2000} & İhracat & 66.774 & 114.429 & 60.878 & 253.092 & 37.034 \\
\hline & Itthalat & 81.611 & 62.417 & 65.124 & 224.306 & 33.107 \\
\hline \multirow[t]{2}{*}{2001} & İhracat & 69.203 & 113.116 & 60.963 & 272.060 & 35.694 \\
\hline & İthalat & 81.470 & 74.250 & 65.218 & 243.973 & 30.897 \\
\hline \multirow[t]{2}{*}{2002} & İhracat & 72.286 & 121.649 & 73.452 & 333.002 & 36.701 \\
\hline & Ithalat & 68.004 & 84.408 & 78.498 & 295.619 & 32.316 \\
\hline \multirow[t]{2}{*}{2003} & İhracat & 84.757 & 151.697 & 90.838 & 447.958 & 47.117 \\
\hline & İthalat & 72.356 & 102.759 & 95.071 & 412.137 & 42.967 \\
\hline \multirow{2}{*}{2004} & İhracat & 110.743 & 203.415 & 126.647 & 607.356 & 58.215 \\
\hline & Ithalat & 87.897 & 130.992 & 139.310 & 556.182 & 58.544 \\
\hline \multirow[t]{2}{*}{2005} & İhracat & 135.918 & 268.957 & 160.837 & 773.339 & 68.172 \\
\hline & Ithalat & 105.595 & 164.341 & 183.736 & 648.712 & 68.831 \\
\hline \multirow[t]{2}{*}{2006} & İhracat & 159.215 & 333.908 & 199.973 & 991.731 & 79.519 \\
\hline & İthalat & 129.232 & 207.914 & 229.955 & 782.812 & 84.217 \\
\hline \multirow{2}{*}{2007} & íhracat & 186.198 & 392.044 & 253.077 & 1.258 .056 & 93.339 \\
\hline & İthalat & 167.160 & 279.983 & 302.803 & 950.020 & 97.337 \\
\hline \multirow[t]{2}{*}{2008} & İhracat & 229.512 & 520.003 & 288.902 & 1.497 .868 & 102.154 \\
\hline & Ithalat & 232.727 & 366.597 & 350.927 & 1.149 .036 & 106.801 \\
\hline \multirow[t]{2}{*}{2009} & İhracat & 180.894 & 341.583 & 273.751 & 1.262 .664 & 82.601 \\
\hline & Ithalat & 187.616 & 250.604 & 347.177 & 1.042 .533 & 81.401 \\
\hline \multirow[t]{2}{*}{2010} & İhracat & 240.006 & 445.513 & 375.353 & 1.654 .815 & 107.407 \\
\hline & İthalat & 263.001 & 322.366 & 449.974 & 1.432 .415 & 102.747 \\
\hline \multirow[t]{2}{*}{2011} & ihracat & 303.021 & 573.991 & 447.383 & 2.006 .296 & 126.845 \\
\hline & Ithalat & 323.150 & 408.776 & 566.667 & 1.825 .402 & 123.475 \\
\hline \multirow[t]{2}{*}{2012} & İhracat & 292.804 & 594.193 & 448.400 & 2.175 .080 & 117.805 \\
\hline & Ithalat & 326.310 & 447.048 & 571.306 & 1.943 .215 & 123.559 \\
\hline \multirow[t]{2}{*}{2013} & İhracat & 290.362 & 592.497 & 472.180 & 2.354 .248 & 113.611 \\
\hline & İthalat & 347.274 & 468.623 & 527.555 & 2.119 .378 & 122.045 \\
\hline \multirow[t]{2}{*}{2014} & İhracat & 270.452 & 558.283 & 468.346 & 2.462 .839 & 110.424 \\
\hline & Ithalat & 335.819 & 426.062 & 529.239 & 2.241 .288 & 115.678 \\
\hline \multirow[t]{2}{*}{2015} & İhracat & 232.489 & 391.450 & 416.787 & 2.362 .092 & 95.771 \\
\hline & İthalat & 253.273 & 281.490 & 465.097 & 2.003 .257 & 99.936 \\
\hline \multirow[t]{2}{*}{2016} & İhracat & 224.011 & 330.136 & 439.642 & 2.199 .967 & 90.628 \\
\hline & İthalat & 216.830 & 263.794 & 480.169 & 1.944 .484 & 89.076 \\
\hline \multirow[t]{2}{*}{2017} & İhracat & 258.207 & 411.264 & 498.107 & 2.424 .199 & 103.564 \\
\hline & Ithalat & 237.622 & 326.912 & 583.123 & 2.208 .504 & 99.085 \\
\hline \multirow[t]{2}{*}{2018} & İhracat & 276.656 & 509.551 & 536.623 & 2.655 .609 & 110.144 \\
\hline & Ithalat & 266.778 & 344.262 & 642.698 & 2.548 .985 & 108.878 \\
\hline
\end{tabular}

Kaynak: World Bank, (2020).

Tablo 1'de 2000-2018 dönemleri açısından BRICS ülkelerinin dıș ticaret verileri ABD doları olarak incelenmiştir. Buna göre BRICS ülkelerinin dünya ihracatındaki payının 2001 yılından itibaren artış sağladığı görülmektedir. BRICS ülkelerinde en yüksek ihracat hacmine sahip ülke Çin'dir. Çin'i takip eden ülkeler ise sırasıyla Rusya, Hindistan, Brezilya ve Güney Afrika olmuştur. İthalat hacmi açısından incelediğimizde yine ilk sırada Çin yer almakta ve onu sırasıyla Hindistan, Rusya, Brezilya ve Güney Afrika takip etmektedir.

Dış ticaret hacmine göre ihracat ve ithalatta ilk sırada yer alan Çin'in ihracatında meydana gelen artışı arkasında, ithalatta uygulanan serbestleşme politikaları ve yabancı piyasalara yönelik üretim gerçekleştiren firmalara sağlanan teşvikler yer almaktadır. Ayrıca ithal edilen makine ve temel girdiler üzerine uygulanan vergi ve tarife indirimlerinin düşürülmesi, doğrudan nakit akışının 
sağlanması ve finans piyasalarına kolay bir şekilde giriş sağlanması ülkede ihracatın artmasına neden olan temel faktörler arasında sıralanabilir. Çin'in uluslararası ticareti özellikle 1979 yılında ekonominin dışa açılması ile birlikte hız kazanmıştır. İhracat açısından değerlendirildiğinde az gelişmiş ülkelere hammadde ve gıda maddeleri ile birlikte başlayan ve devamında kitle üretim malları imalatında güçlü bir artışa geçen Çin'in ihracatı sonuçta ekonomi açısından güç, verimlilik ve olgunluğun simgesi olarak ileri teknoloji ve sermaye mallarına dönüşen geleneksel kalkınma aşamasını yansıtmaktadır. Çin'in dış ticaret dengesi incelendiğinde 2000 yılından bu yana sürekli dış ticaret fazlası verdiği görülmektedir. 2008 yılında yaşanan küresel finansal kriz özellikle ihracat sektörünü sert bir şekilde etkilediği için Çin ekonomisinde de ciddi hasarlara yol açmıştır. Nitekim bu dönemde daha önce ürettiği ve ihraç ettiği malların çoğunu artık kendi iç piyasasına satmak zorunda kalmıştır. 2015 yılında yaşanan Çin ekonomisini korumaya yönelik develüasyon politikaları ise küresel piyasalarda olumsuz sonuçlara yol açmış ve diş ticareti de etkilemiştir.

İhracat siralamasinda 2. sirada, ithalat siralamasinda ise 3. sirada yer alan Rusya, 2000 yılından itibaren Ruble'nin değer kazanmaya başlaması ve petrol ihracat gelirlerindeki artış ile birlikte yükselen ihracat miktarının diğer BRICS ülkeleri gibi 2008 küresel finansal krizden etkilendiği görülmektedir. Global mali krizden kaynaklı iç talepte bir düşüş yaşanmış ve dolayısıyla ülkenin ithalat hacmi de 2009 yılında önemli düzeyde daralma sürecine girmiştir. Küresel finansal krizden her ne kadar toparlanmış gibi görülse de petrol fiyatlarında yaşanan düşüş ve Ruble'de yaşanan değer kaybı ile birlikte dış ticaret hacmi 2014 yılında \%8 oranında azalmıştır. Rusya'nın genel olarak ticaret faaliyetlerindeki olumlu gelişiminin arkasında komünizmin terk edilmesi yer almaktadır. Ayrıca özellikle Putin dönemiyle beraber ulusal düzeyde daha fazla önemi artan, uluslararası platformda ise hem işbirliği hem de siyasi ve ekonomik alanlarda etkili bir pazarlık kartı olarak kullanılan enerji sektörü ve Rusya'nın dünyanın en önemli enerji tedarikçilerinden biri olması bağlamında (Köksoy, 2020:126) Batı ülkeleri özellikle de Avrupa ülkeleri ile petrol ve doğal gaz ihracatının geliştirilmesi sonucunda ihracat hacminde olumlu gelişmeler gözlemlenmiştir.

Hindistan ekonomisi bilindiği üzere kapalı bir ekonomik yapıya sahiptir. Dolayısıyla dünya ekonomisinde yaşanan olumlu ya da olumsuz gelişmelerin ülkeye yansıması da geç olmakta ve ülkeyi fazla etkilememektedir. Hindistan, 1991 yılında dışa açık bir politika izlemesi ve aynı zamanda liberal yatırım ve ekonomi politikası ile küresel piyasada önemli bir yere gelmiştir. BRICS sıralamasında ihracatta 3 . sirada ve ithalatta da 2 . sırada yer aldığ görülmektedir. İhracatının artmasında, ihracatı arttırmaya yönelik teşviklerin sağlanması yer almaktadır. Ayrıca 2006 yılında hükümet tüm ithal mallarına \%4 oranında ad valorem "ekstra ek vergi" uygulamaya başlamıştır. Söz konusu teşviklerle birlikte tablo 1'de görüleceği üzere dış ticarette artışlar yaşandığg gözlenmektedir. Hindistan ekonomisinde yaşanan pozitif yönlü gelişmelerin arkasında uluslararası piyasalarda yaşanan olumlu gelişmelerin önemi olmakla birlikte yapısal reformlar yoluyla da ülke ekonomisi önemli bir konuma gelmektedir. Bu bağlamda Hindistan ekonomisinin, önümüzdeki dönemde Asya ekonomileri ve bu ekonomilerin diğer ülke ekonomileri üzerinde oldukça pozitif etkiler yaratacağı beklenmektedir.

BRICS dış ticaret sıralamasında 4. sırada yer alan Brezilya, 1990'lı yıllarda içe dönük ithal ikameci sanayileşme politikasını terk ederek dışa dönük (ihracata dayalı) sanayi uygulamasına geçmiştir. Dışa dönük sanayileşme politikası ile beraber ithal malların üzerine uygulanan birçok tarife dışı engeller kaldırılmış ve bununla birlikte tarife oranları azaltılmışırır. Latin Amerika'nın en büyük ülkesi olan Brezilya'nın dış ticaret verileri incelendiğinde, 2003-2007 yıllarında dış fazla veren Brezilya, 2008 yılında yaşanan küresel finansal kriz ile birlikte açık vermeye başlamıştır. Brezilya'nın enerji kaynakları açısından zengin bir ülke olması ve özellikle savunma sanayisine yönelik üretim yapması 2015 yılından sonra ihracatının artmasına neden olmuştur. Brezilya'nın ihracatta sergilemiş olduğu başarının altında ihracat mallarının çeşitlendirilmesi ve geleneksel pazarlar dışındaki diğer alanlara yönelmesi yer almaktadır. Brezilya'nın, Rusya, Hindistan ve Çin ile birlikte 2050 yıllarında dünyanın ekonomik kaderini belirleyecek ülkeler arasında yer alacağı tahmin 
edilmektedir. Söz konusu bu tahminin arkasında ülkenin gelecekte büyük bir etki yaratacak zengin doğal kaynaklarına sahip olması yer almaktadır.

2010 yılında BRICS topluluğuna dâhil olan Güney Afrika'nın ekonomisi küresel makroekonomik nedenlerden dolayı son zamanlarda oldukça zayıf performans sergilemektedir. 1970'li yıllarda ithal ikameci stratejiden ihracata yönelik sanayileşme stratejisine geçen Güney Afrika'nın dış ticaretinin gelişmesinde bölgesel entegrasyonlar ve diğer ülkelerle yapılan ticaret etkili olmuştur. 2010 yılında BRIC topluluğuna girmesiyle tablo 1'den de anlaşılacağ 1 üzere sürekli dış fazla verdiği görülmektedir. Hem ihracatta hem ithalatta en büyük paya sahip olan ticaret ortağ 1 ülke ise Çin'dir. Güney Afrika'nın en önemli ihracat ürünleri altın ve pırlanta gibi değerli madenler olmasından dolayı BRICS ülkelerinin Afrika'da doğal kaynaklara erişimini kolaylaştırmaktadır.

Tablo 2: 2000-2020 Yilları Arasında Reel GSYİH Büyüme Oranları (Ortalama Yı1lık Değişim \%)

\begin{tabular}{|l|l|l|l|l|l|l|l|l|l|l|}
\hline Ülkeler & $\begin{array}{l}\mathbf{2 0 0 0} \\
\mathbf{2 0 0 5}\end{array}$ & $\mathbf{2 0 0 9}$ & $\mathbf{2 0 1 0}$ & $\mathbf{2 0 1 1}$ & $\mathbf{2 0 1 2}$ & $\mathbf{2 0 1 3}$ & $\mathbf{2 0 1 4}$ & $\mathbf{2 0 1 5}$ & $\mathbf{2 0 1 6}$ & $\mathbf{2 0 2 0}$ \\
\hline Brezilya & 2,8 & $-0,2$ & 7,5 & 3,9 & 1,8 & 2,7 & 0,1 & $-1,0$ & $-1,0$ & 2,5 \\
\hline Rusya & 6,2 & $-7,9$ & 4,8 & 4,3 & 3,4 & 1,3 & 0,6 & $-3,8$ & $-0,6$ & 1,5 \\
\hline Hindistan & 6,9 & 7,4 & 10,4 & 6,6 & 5,1 & 6,9 & 7,2 & 7,2 & 7,5 & 7,8 \\
\hline Çin & 9,6 & 8,7 & 10,3 & 9,3 & 7,8 & 7,8 & 7,4 & 6,8 & 6,3 & 6,3 \\
\hline $\begin{array}{l}\text { Güney } \\
\text { Afrika }\end{array}$ & 4,0 & $-2,1$ & 1,9 & 3,2 & 2,2 & 2,2 & 1,5 & 2,0 & 2,1 & 2,8 \\
\hline $\begin{array}{l}\text { BRICS } \\
\text { Ortalama }\end{array}$ & 5,9 & 1,18 & 6,98 & 5,46 & 4,06 & 4,18 & 3,36 & 2,24 & 2,86 & 4,18 \\
\hline
\end{tabular}

Kaynak: Ersungur vd., (2017).

Tablo 2'de BRICS ülkelerinin 2000-2020 yılları arasında reel GSYİH büyüme oranlar1 gösterilmektedir. Burada Çin'in 2000-2005 ve 2010 dönemlerinde $\% 9,6$ ve \%10,3 büyüme oranları görülmekle birlikte Hindistan'ın da söz konusu dönemlerde $\% 6,9$ ve $\% 10,4$ oranlarında bir büyüme görülmektedir. Söz konusu ülkelerde büyüme oranlarının yüksek çıkmasının arkasında yatan nedenler arasında, düşük işgücü ve düşük maliyetli kaynak kullanımı imkânına sahip olmaları yer almaktadır. Rusya'da 2000-2005 ve 2010 dönemlerinde dünyada yaşanan enerji fiyatlarındaki artışa bağlı olarak büyüme de yüksek düzeylerde gerçekleşmiş̧ir. 2009 yılındaki küresel finansal krizin enerji fiyatlarına yansıması ile birlikte büyüme oranları da olumsuz yönde etkilenmiştir. Son olarak BRICS grubunda yer alan Brezilya'da ise en yüksek büyüme oranı 2010 y1lında \%7,5 ile gerçekleşmiştir. 2020 yılının ilk çeyreğinde açıklanan veriler incelendiğinde ise Hindistan'ın daha yüksek büyüme oranına sahip olduğu ve ikinci sırada Çin'in geldiği görülmektedir. 
Grafik 1: BRICS Ülkelerinin Dış Borç ve Büyüme İstatistikleri (\%)

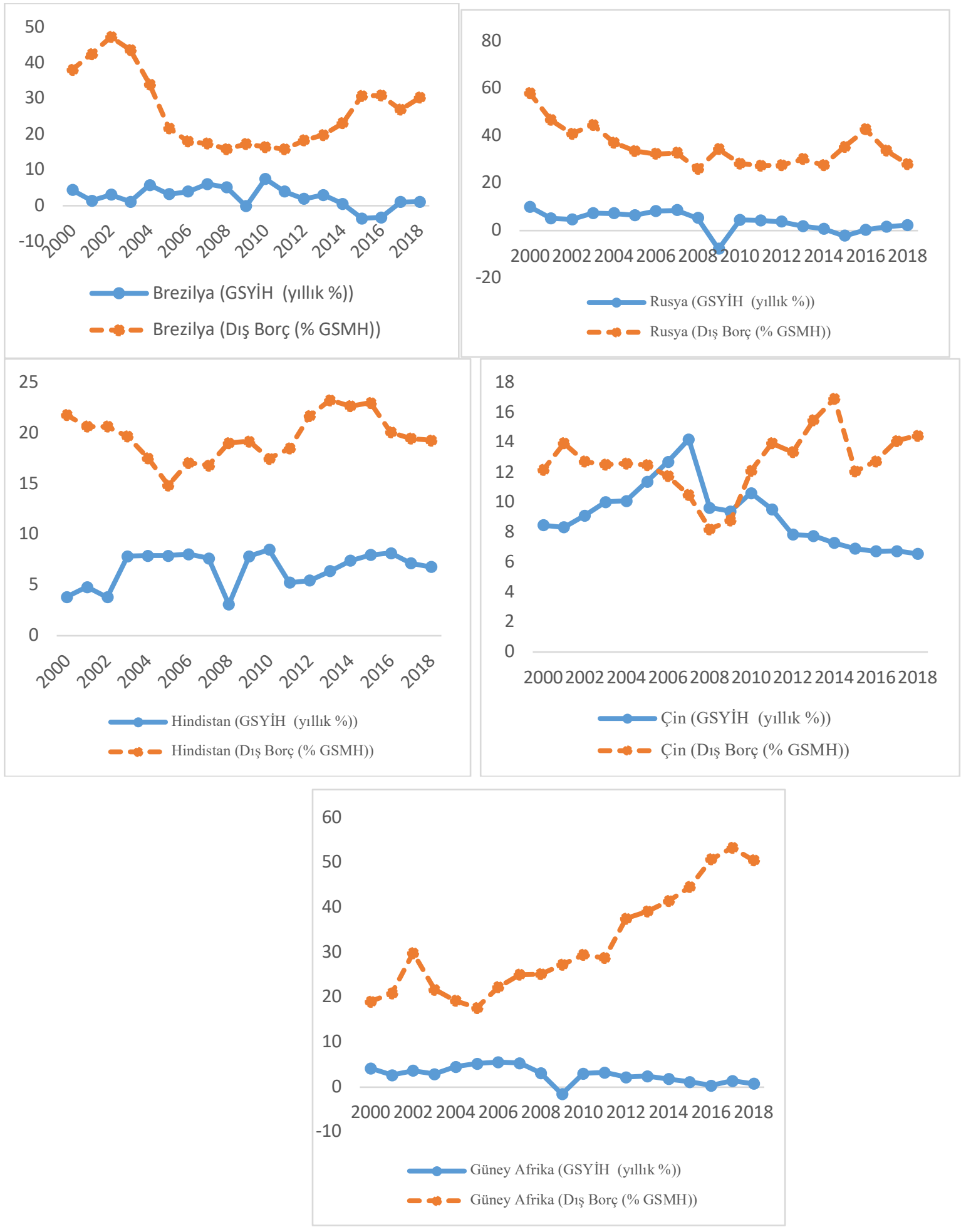

Kaynak: World Bank, (2020)

Grafik 1'de BRICS ülkelerinin dış borç ve büyüme oranları gösterilmektedir. İlk olarak dünyanın 9. büyük ekonomisi olan Brezilya ekonomisi incelendiğinde, Brezilya’nın küresel finansal 
krizden ciddi bir olumsuzluk yaşamadan 2013 yılına kadar gelişimine devam ettiğini söylemek mümkündür. 2013 yılında ise ulaşım ücretlerine zam yapılmas1 ve hükümette meydana gelen yolsuzlukların ortaya çıkmasıyla birlikte resesyonist döneme girilmiştir. Bu dönemde dış borçların arttığ 1 ve büyümede ciddi düşüşlerin yaşandığı gözlemlenmektedir. 2016 yılında ulusal para birimi olan Real'in değer kaybı ve ihracatta yaşanan artışlar ekonomideki olumsuz havanın devam etmesine neden olmuştur. 2017 yılında \%1'lik bir büyüme ile resesyondan çıkan Brezilya emtia fiyatlarında meydana gelen artışlar, iç talepte toparlanma, ihracatın ve emeklilik reformların toparlanmasıyla birlikte ekonomi de toparlanma sürecine girmiştir. Brezilya'nın dış borç ve büyüme verileri incelendiğinde genel olarak ters yönlü bir ilişkinin olduğunu söylemek mümkündür. Kısaca dış borçlarda meydana gelen artışlar büyümeyi olumsuz etkilerken, dış borçlarda meydana gelen düşüşler ise büyümeyi olumlu etkilemektedir.

İkinci olarak dünya ekonomisinin 12. büyük ekonomisi konumunda olan Rusya incelendiğinde, 2000'li yıllardan sonra yolsuzluğun azaltılması ve gelir seviyesinin yükseltilmesiyle birlikte 2008 küresel finansal krize kadar önemli bir başarı sergilediği gözlenmektedir. Bu başarının arkasında ise petrol ve doğalgaz fiyatlarında meydana gelen artışlar ve bunlardan elde edilen gelirler yer almaktadır. 2014 yılında yaşanan jeopolitik sorunlar, karşılıklı yaptırım uygulamaları ve petrol fiyatlarındaki gerileme olumlu yönde ilerleyen ekonomisini olumsuz yönde etkilemiştir. Bu süreç 3 y1l sürmüş ve 2017 yılından itibaren diş küresel talepte yaşanan artışlar ile birlikte toparlanmaya başlamıştır. Son zamanlarda Rusya'nın AB ve ABD ile yaşamış olduğu diplomatik gerilimler ticari gerilimlerin de derinleşmesine neden olmaktadır. Rusya'nın dış borç ve büyüme ilişkisine bakıldığında ters yönlü ilişkinin olduğu yani dış borçlarda meydana gelen artışların büyümeyi olumsuz yönde etkilediği görülmektedir.

Dünya ekonomisinin 7. büyük ülkesi olan Hindistan hızlı nüfus artışı ile birlikte ilerde Çin'in rakibi olarak ön plana çıkabilecek bir ekonomik yapıya sahiptir. Diğer BRICS ülkeleri gibi Hindistan da küresel finansal krizden ciddi anlamda etkilenmiştir. 2010 yılında yaşanan yüksek enflasyon oranları sonucunda ekonominin daralma sürecine girdiğini gözlemlemek mümkündür. 2016 yılında ise 500 ve 1000 rupilik banknotların piyasadan çekilmesine yönelik alınan kararlar ve Temmuz 2017'deki vergi düzenlemelerin etkisiyle 2017'de yavaşlayan büyümenin 2018'den itibaren yükseldiğini gözlemlemek mümkündür. 2019 yılında petrol fiyatlarındaki düşüş ve enflasyonist baskının hafiflemesi ile birlikte büyüme hızında artış meydana gelmiştir. 2020 yılında Hindistan hükümetinin uygulamış olduğu teşvik programları ile birlikte en büyük ilk 5 ekonomi arasında yer alması beklenmektedir. Dış borç ve büyüme ilişkisine bakıldığında grafikten de anlaşılacağı üzere genel olarak ters yönlü bir ilişki söz konusu olmaktadır.

Dünyanın 2. büyük ekonomisi olan Çin en kalabalık ve en hızlı büyüyen bir nüfusa sahiptir. 2008 yılında yaşanan küresel finansal krizle birlikte Çin ekonomisinde de yavaşlama görülmüştür. $\mathrm{Bu}$ dönemde Çin hükümetinin büyük bir teşvik paketini ve geniş para politikasını uygulamaya geçirmesiyle birlikte iç yatırım ve tüketim artarak ekonomide yaşanan aşırı 1sınmayı önlemeyi başarmıştır. 2009 yılından 2011 yılına kadar, Çin'in reel GSYIH büyüme oranı ortalama \% 9,7 seviyelerinde olurken 2012 yılından itibaren yavaşlamaya başlamış ve \%7 civarında bir büyüme gerçekleşmiştir. Çin ekonomisinin artık "yeni normal” olarak adlandırdığı düşük ancak sürdürülebilir büyüme eğilimi devam etmiştir. 2018 yılında ABD ile artan ticaret savaşları ve devam eden yüksek borçlardan dolayı finansal riskleri yavaşlatma çabaları sonucunda Çin ekonomisi \%6,6 ile son 29 yılın en düşük büyüme oranını kaydetmiştir. Grafik 1 incelendiğinde büyüme oranları ve dış borç arasında ters yönlü bir etkinin olduğu görülmektedir. Yani Çin'in dış borçlarının artmasıyla birlikte büyümenin de yavaşladığg gözlemlenmektedir.

Dünyanın 34. büyük ekonomisi konumunda olan Güney Afrika, Çin'in en büyük ticaret ortaklarındandır. Dolayısıyla Çin ekonomisinde meydana gelen yavaşlama Güney Afrika ülkesine de yansımakta ve negatif bir etkiye neden olmaktadır. Ülke kalıcı olarak zayıf ekonomik bir görünüm 
sergilemekte ve bunun altında yatan nedenler arasında özel sektör yatırımları, ihracattaki durgunluk ve düşük verimlilik yer almaktadır. 2010 yılında BRIC topluluğuna katılmasıyla birlikte gurubun Afrika'ya açılan kapısı özelliği taşımaktadır. Güney Afrika'nın zengin yeraltı kaynakları, tarım ürünleri üretimi ve sanayisini geliştirmeye yönelik politikalar geliştirmesi ile birlikte dış ticaret etkisini arttırmıştır. Yapısal değişim çalışmaları kapsamında yatırım ve ihracatın da etkisiyle birlikte reel büyüme yönünde de önemli adımlar atılmıştır. 2011 yılında \%3,2 oranında büyüme gerçekleşse de ihracatta meydana gelen düşüş ekonomiyi olumsuz yönde etkilemiştir. 2016 y1lında \%0,36'l1k büyüme ile küresel finansal krizden sonra en düşük büyüme seviyesi görülmüştür. 2015 y1lında yaşanan emtia fiyatlarındaki düşüş, devalüasyonlar, borç sürdürülebilirliğinde yaşanan sorunlar ve güvenlik tehditleri ekonomiyi olumsuz etkilemiştir. Artan işsizlik ve gelir eşitsizliğinin yaşandığı Güney Afrika'nın uzun dönemli zayıf bir ekonomik büyüme ile karşı karşıya kalması ve bu durumun 2020 yılında da devam etmesi halinde risk grubunda yer alması muhtemel görülmektedir. Grafik 1 incelendiğinde özellikle 2005 yılından itibaren büyüme ve dış borç arasındaki makasın daha fazla açıldığı görülmektedir. Dış borç ve büyüme arasında ters yönlü bir ilişkinin yani dış borç arttıkça büyümenin düşük olduğunu söylemek mümkündür.

\section{3. $\quad$ MINT Ülkeleri İle Dış Borç ve Büyüme Arasındaki İlişsi}

Dört ülke grubuna, yani Meksika, Endonezya, Nijerya ve Türkiye'ye atıfta bulunan MINT kısaltması, ilk olarak 2014 yılında Boston merkezli bir varlık yönetim şirketi olan Fidelity Investments tarafından oluşturulmuştur. Her ne kadar bu yeni terim Fidelity projelerine göre öncelikle ekonomik ve finansal alanlarda ve akademide kullanılmış olsa da, bu ülkeler önümüzdeki on yıl boyunca güçlü büyüme gösterebilir ve yatırımcılara yüksek getiri sağlayabilir (Gryczka, 2018).

O'Neill'in BRICS terimini ortaya attığında bu guruba dâhil etmediği fakat bu kapsamda değerlendirdiği ülkelerin de olduğu söylenebilir. Meksika, Endonezya, Nijerya ve Türkiye'yi kapsayan bu ülkeler 2014 yılının başlangıcından itibaren "yükselen devler" olarak nitelendirilmiş ve ülkelerin baş harflerinin bir araya getirilmesiyle İngilizce de nane anlamına da gelen MINT kelimesiyle tanımlanmıştır. Aynı zamanda BRICS ülkelerine de rakip olarak gösterilmektedir (Yalçınkaya \& Temelli, 2014:203).

Geleceğe yönelik ekonomik beklentileri parlak olan MINT ülkeleri, BRICS ülkelerinden sonra gelen ekonomik güç olarak faaliyet gösteren bir ülke gurubudur. MINT ülkelerinin ortak özelliklerinden birisi de hızlı büyüyen genç ve dinamik bir iş gücü kaynağına sahip olmasıdır (Bal vd., 2017:36). Bu ülkelerin nüfusu 80 milyon (Türkiye) ile 240 milyon (Endonezya) arasında değişmektedir. Coğrafi olarak, MINT ülkelerinin her biri büyük pazarların yakınında olması ile konum avantajı da elde etmiştir. Şöyle ki Meksika sınırını ABD ve Latin Amerika'ya komşu ülkelerle paylaşmakta, Endonezya, Çin ile Güneydoğu Asya arasındaki bağlantıda yer almakta ve Türkiye ise batı ile doğu arasında bir köprü görevi üstlenmektedir (Satoğlu, 2017:256). Diğer taraftan Meksika, Endonezya ve Nijerya hammadde üreticisi ülkelerdir ve sadece Nijerya gelişmiş ve gelişmekte olan ülkeler grubunda yer alan G-20 grubunun üyesi değildir (Durotoye, 2014: 99). Aşağıdaki tabloda BRICS ülkeleri ve MINT ülkelerinin benzerlikleri ve farklı yönlerinden bahsedilmektedir. 
Tablo 3: BRICS ve MINT'ler: Temel Benzerlikler ve Farklıliklar

\begin{tabular}{|c|c|}
\hline BRICS & MINT \\
\hline $\begin{array}{l}\text { BRIC dört ülkeden oluşmaktaydı ancak daha sonra } \\
\text { Güney Afrika'nın katılımıyla beş BRIC ülkesi haline } \\
\text { gelmiştir. }\end{array}$ & MINT dört ülkeden oluşmaktadır. \\
\hline $\begin{array}{l}\text { BRICS ülkeleri dört kıtada (Asya, Avrupa, Afrika ve } \\
\text { Güney Amerika) bulunmaktadır. }\end{array}$ & $\begin{array}{l}\text { MINT ülkeleri dört kıtada (Avrupa, Asya, Kuzey } \\
\text { Amerika ve Afrika) bulunmaktadır. }\end{array}$ \\
\hline $\begin{array}{l}\text { BRICS ülkelerinden üçü net doğal kaynak } \\
\text { ihracatçısıdır (Brezilya, Rusya ve Güney Afrika) ve } \\
\text { ikisi net büyük doğal kaynak ithalatçısıdır } \\
\text { (Hindistan ve Çin). Aynı zamanda, Hindistan ve Çin } \\
\text { Halk Cumhuriyeti, sanayi ürünlerinin en büyük } \\
\text { ihracatçları arasında yer almaktadır. }\end{array}$ & $\begin{array}{l}\text { MINT ülkelerinden üçü net doğal kaynak } \\
\text { ihracatçısıdır (Endonezya, Meksika ve özellikle } \\
\text { Nijerya). Türkiye, net doğal kaynak ithalatçısı olup, } \\
\text { aynı zamanda endüstriyel ürünlerin ihracatçısı ve } \\
\text { ithalatçı1sı konumundadır. Demografik olarak, } \\
\text { BRICS ülkeleri üç genç ve dinamik nüfustan (Güney } \\
\text { Afrika, Hindistan ve Brezilya), bir olgun nüfustan } \\
\text { (P.R. Çin) ve bir yaşlanan, durgunlaşan nüfustan } \\
\text { (Rusya) oluşmaktadır. }\end{array}$ \\
\hline $\begin{array}{l}2014 \text { yılı itibarıla, Dünya Bankası verilerine göre } \\
\text { piyasa fiyatları GSYH verilerine göre, BRICS } \\
\text { dünyanın ikinci (Çin), yedinci (Brezilya), } \\
\text { dokuzuncu (Hindistan), onuncu (Rusya) ve otuzuncu } \\
\text { (Güney Afrika) ekonomisini icermektedir. }\end{array}$ & $\begin{array}{l}2014 \text { yılı itibarıyla Dünya Bankası verilerine göre } \\
\text { piyasa fiyatları GSYH verilerine göre MINT'ler } \\
\text { dünyanın 15. (Meksika), 16. (Endonezya), } 17 . \\
\begin{array}{llll}\text { (Türkiye) ve } 21 . & \text { (Nijerya) ekonomisinden } \\
\text { olusmaktadır. }\end{array}\end{array}$ \\
\hline
\end{tabular}
Kaynak: Kokotovic, F. \& Peter, K. (2016).

MINT ülkelerinde ekonomik gelişmelerin arkasında, gerçekleştirilen akıllı hamleler yer almaktadır. Türkiye'nin ihracatını arttırarak cari açıkta meydana gelen açığı kapatma ve ekonomik büyümeyi arttırma çabaları, Meksika'nın petrole yönelik yatırımları ve işçi dövizlerini ülkesine çekme çabaları, Nijerya'nın tarıma yönelik yatırımlarını arttırma çabaları ve Endonezya'nın hammadde ihracatı ile birlikte üretimi arttırmaya yönelik çabaları söz konusu bu ülkelerin neden bir araya geldiğinin bir diğer göstergesidir. MINT ülkelerinin sayılan bu avantajları elde edebilmesi için hızlı ve istikrarlı bir büyüme gerçekleştirebilmeleri ile birlikte uygulamaya geçirecekleri politikalara bağlı olmaktadır. Geliş̧mekte olan ülkeler kapsamında değerlendirilen ve aynı zamanda sermaye birikiminin yeterli olmadığ bu ülkelerde büyümenin sağlanabilmesi için yerli ve yabancı sermaye yatırımları gerekli olmaktadır. Daha fazla yatırım çekebilmek için yatırımcı haklarının korunması ve kurumsal yapının güçlü olması gerekmektedir. Bu doğrultuda söz konusu bu ülkelerin belirtilen firsatları kullanarak ekonomik reformlar ile birlikte kurumsal yapılarının da güçlendirilmesi hedeflenen verilere ulaşabilmesi için önemlidir (Hayaloğlu, 2015). 
BRICS ve MINT Ülkelerinde Dış Borç İle Büyüme Arasındaki İlişkinin Değerlendirilmesi... 1689

Tablo 4: MINT Ülkelerinin 2000-2018 Dönemleri Dış Ticaret Verileri (Current ABD \$)

\begin{tabular}{|c|c|c|c|c|c|}
\hline & & Meksika & Endonezya & Nijerya & Türkiye \\
\hline \multirow{2}{*}{2000} & İhracat & 179.855 & 67.621 & 25.017 & 53.091 \\
\hline & İthalat & 191.318 & 50.264 & 9.009 & 61.561 \\
\hline \multirow{2}{*}{2001} & İhracat & 171.520 & 62.625 & 20.914 & 53.222 \\
\hline & İthalat & 185.388 & 49.355 & 15.864 & 45.699 \\
\hline \multirow{2}{*}{2002} & İhracat & 174.129 & 63.956 & 22.167 & 58.321 \\
\hline & İthalat & 186.428 & 51.638 & 16.020 & 54.838 \\
\hline \multirow{2}{*}{2003} & İhracat & 177.669 & 71.553 & 28.065 & 69.359 \\
\hline & İthalat & 188.498 & 54.323 & 23.692 & 72.836 \\
\hline \multirow{2}{*}{2004} & İhracat & 222.268 & 82.744 & 27.623 & 92.090 \\
\hline & İthalat & 234.749 & 70.744 & 15.878 & 102.691 \\
\hline \multirow{2}{*}{2005} & İhracat & 266.557 & 97.387 & 37.047 & 105.386 \\
\hline & İthalat & 280.628 & 85.533 & 21.181 & 122.442 \\
\hline \multirow{2}{*}{2006} & İhracat & 266.526 & 113.143 & 69.688 & 119.615 \\
\hline & İthalat & 280.595 & 93.411 & 30.812 & 146.412 \\
\hline \multirow{2}{*}{2007} & İhracat & 289.778 & 127.226 & 58.532 & 143.399 \\
\hline & İthalat & 308.103 & 109.755 & 49.889 & 176.168 \\
\hline \multirow{2}{*}{2008} & İhracat & 307.483 & 152.090 & 86.517 & 174.469 \\
\hline & İthalat & 333.835 & 146.706 & 50.982 & 206.982 \\
\hline \multirow{2}{*}{2009} & İhracat & 244.407 & 130.357 & 54.378 & 145.518 \\
\hline & İthalat & 259.328 & 115.216 & 50.869 & 150.580 \\
\hline \multirow{2}{*}{2010} & İhracat & 314.142 & 183.480 & 93.240 & 157.844 \\
\hline & İthalat & 328.581 & 169.158 & 64.169 & 196.452 \\
\hline \multirow{2}{*}{2011} & İhracat & 366.385 & 235.095 & 129.735 & 185.339 \\
\hline & İthalat & 382.867 & 212.996 & 88.882 & 253.091 \\
\hline \multirow{2}{*}{2012} & İhracat & 387.538 & 225.744 & 144.917 & 206.848 \\
\hline & İthalat & 402.385 & 229.362 & 59.653 & 249.766 \\
\hline \multirow{2}{*}{2013} & İhracat & 398.972 & 218.308 & 92.950 & 211.715 \\
\hline & İthalat & 413.674 & 225.519 & 66.940 & 266.904 \\
\hline \multirow{2}{*}{2014} & İhracat & 419.247 & 210.820 & 104.803 & 222.003 \\
\hline & İthalat & 434.739 & 217.485 & 70.778 & 258.300 \\
\hline \multirow{2}{*}{2015} & İhracat & 404.586 & 182.158 & 52.706 & 200.727 \\
\hline & İthalat & 428.461 & 178.863 & 53.366 & 223.151 \\
\hline \multirow{2}{*}{2016} & İhracat & 399.503 & 177.886 & 37.301 & 189.717 \\
\hline & İthalat & 420.784 & 170.835 & 46.552 & 214.639 \\
\hline \multirow{2}{*}{2017} & İhracat & 436.348 & 204.999 & 49.491 & 211.240 \\
\hline & İthalat & 457.355 & 194.699 & 49.508 & 249.702 \\
\hline \multirow{2}{*}{2018} & İhracat & 479.604 & 218.498 & 61.552 & 227.780 \\
\hline & İthalat & 502.427 & 229.861 & 69.551 & 236.243 \\
\hline
\end{tabular}

Kaynak: World Bank, 2020.

Tablo 4'te 2000-2018 dönemleri açısından MINT ülkelerinin dış ticaret verileri ABD doları olarak incelenmiştir. Buna göre MINT ülkelerinin ihracat ve ithalat değerlerinin 2001 yılından itibaren artış sağladığı görülmektedir. MINT ülkeleri içerisinde ihracat hacminin en fazla görüldüğü ülke Meksika'dır. Meksika'yı takip eden ülkeler ise sırasıyla Türkiye, Endonezya ve Nijerya olmuştur. İthalat hacmi açısından incelendiğinde yine ilk sırada Meksika yer almakta ve onu sirasıyla Türkiye, Endonezya ve Nijerya takip etmektedir.

Diş ticaret hacmine göre ihracat ve ithalatta ilk sırada yer alan Meksika ortalama 450 milyar dolarlık ihracatıyla dünyanın en çok ihracat yapan 12. ülke konumundadır. 1980'li yıllarda yaşanan ekonomik dönüşüm ve 1994 yılında imzalanan Kuzey Amerika Serbest Ticaret Anlaşması'nın (NAFTA) etkisiyle ABD ve Kanada ile ticaretini arttıran Meksika liberal bir ekonomik yapıya 
sahiptir. ABD'nin ticaret savaşı tehditleri ve tek taraflı gümrük tarifelerini arttırmaya yönelik politikaları sonucunda Meksika ve Kanada arasında 2018 yılında USMCA (United States, Mexico, Canada Agreement) anlaşması imzalanmıştır. Meksika ABD'nin en büyük ikinci ihracat pazarı ve üçüncü büyük ithalat kaynağı konumundadır. Dolayısıyla ABD'de başlayan ve tüm dünyaya yayılan küresel finansal kriz Meksika ihracatını ciddi boyutlarda etkilemiştir. İhracatında \%21, ithalatında ise \%24 düşüş yaşayan Meksika 2010 y1lından itibaren toparlanmaya başlamıştır. ABD'ye olan dış ticaret bağımlılığını azaltmak için üçüncü ülkelerle Serbest Ticaret Anlaşması (STA) imzalamış olmasına rağmen 2018 yılında ihracatta ilk sırayı yine ABD almıştır.

İhracat ve ithalatta 2. sırada yer alan Türkiye 1980 yılına kadar içe kapanık ve ithal ikameci politikalar izlemiş ve 24 Ocak kararları ile birlikte ihracata dayalı büyüme ve dünya ekonomisine entegrasyon politikaları ile birlikte dış pazarlara açılmaya başlamıştır. 2001 yılında yaşanan kriz ile birlikte ihracat ve ithalatta ciddi düşüşler yaşanmıştır. 2002 yılından itibaren yeni hükümetin (AKP) gelmesiyle birlikte ekonomi toparlanma aşamasına geçmiştir. Fakat 2008 yılında yaşanan küresel finansal krizden kaynaklı dünya piyasalarında yaşanan daralma Türkiye ekonomisini de etkilemiştir. Krizin etkisiyle birlikte 2009 yılında ihracat ve ithalat rakamları negatif yönlü bir seyir izlemiştir. Türkiye genel olarak tablo 4'ten de anlaşılacağ 1 üzere dış ticaret açığı veren bir ülkedir. Diş ticaret açığının en yüksek olduğu dönem 2011 yılı olmuş ve küresel finansal krizin etkilerini yaşamıştır. Türkiye'de dış ticaret açığına neden olan etkenler arasında; döviz kuru hareketlerine bağlı olarak yatırımların azalması ve ithalatın artması, ithalatın ihracata olan bağlılığı, katma değeri düşük ürünlerin ihracat edilmesi, ileri teknolojiye bağl1 ürünlerin üretilememesinden kaynaklı ülkeye hammadde ve çeşitli kaynakların işlenmeden ihraç edilmesi yer almaktadır. Aynı zamanda 9 Aralık 2016 tarihinde yaşanan Brunson Davası Türkiye'nin dış ticaretinde ciddi kayıplara neden olmuştur. 2018 yılında ise ABD Başkanı Donald Trump'ın yaptırıma yönelik açıklamaları dış ticareti olumsuz yönde etkilemiştir. Türkiye'nin diş ticaretinde yaşanan olumsuz hava, diş ticarette küresel düzeyde yaşanan yavaşlamadan ziyade Türkiye ekonomisinde yaşanan olumsuzluklardan kaynaklandığını söylemek mümkündür. Ülkemizde son dönemde yaşanan sermaye girişindeki düşüşler, cari açığ finanse edecek düzeyde olmamasından dolayı cari açık da olumsuz etkilenmektedir. 2019 yılında ise bir önceki yıla göre \%2,1 oranında artış yaşanmış ve en fazla ihracat Almanya'ya gerçekleşirken en fazla ithalat ise Rusya ile gerçekleşmiştir.

MINT ülkeleri kapsamında dış ticaret sıralamasında 3. sırada yer alan Endonezya, Güneydoğu Asya'daki en büyük ekonomiye ve gelişmekte olan pazar payına sahip bir ülkedir. Tablo 4 incelendiğinde diğer MINT ülkeleri gibi Endonezya da 2008 küresel finansal krizden etkilenmiştir. Fakat bu dönemde hükümetin izlemiş olduğu maliye ve para politikaları nedeniyle diğer bölge ülkelerine göre daha az etkilendiği görülmektedir. Endonezya 2000 yılından itibaren sürekli dış fazla veren bir ülkedir. 2008 yılında Rupiah'ın değer kazanmasıyla birlikte ithalatı önemli ölçüde artmış fakat buna rağmen küresel kriz sürecinde de sürekli dış fazla vermiştir. 2009 yılında hammadde fiyatlarında yaşanan düşüş ithalat ve ihracat değerlerinin düşmesine neden olmuştur. Ülke genç nüfusa ve zengin doğal kaynaklara sahip olmasına karşın döviz kuru dalgalanmalarına ve dış şoklara karşı kırılgan bir yapıya sahiptir. Dolayısıyla 2013 yılında "kırılgan ülke" grubunda yer almıştır. 2012 yılından itibaren dış açık vermeye başlayan Endonezya 2013 yılında hükümetin ithalatı engelleme ve mali reformlarla ihracatı destekleme çalışmaları ticaret dengesi üzerinde olumlu etki yaratmaya başlamıştır. 2018 yılında son on yılın en büyük dış ticaret açığını vermiştir. Endonezya'nın dış ticaret dengesindeki açı̆̆ın temel faktörü ham petrol ve petrol ürünlerinden kaynaklanan 12,4 milyar dolarlık açığa neden olan petrol ve gaz sektörü olmuştur.

Son olarak Nijerya ekonomisi incelenecek olursa Nijerya'nın MINT grubunda dış ticarette son sırada yer aldığını görmek mümkündür. MINT ülke grubunda az gelişmiş ülke konumunda olmasına rağmen petrol ihracatçısı olarak önemli bir konuma sahiptir. Afrika kıtası içerisinde önemli dış ticaret fazlası veren ülkelerden biridir. Nijer Deltası'nda önemli oranda petrol sahasına sahip olan ülke, ihracatını petrol üzerinden gerçekleştirmektedir. Fakat Nijer Deltasında yaşanan siyasi 
gerilimler ve petrol tesislerine yönelik sabotajlar petrol üretimi ve ihracatını da olumsuz etkilemektedir. Tablo 4 incelendiğinde 2011 yılında hem ihracatta hem de ithalatta artışın olduğunu gözlemlenmektedir. Bunun nedenleri arasında 2008 küresel finansal krizden sonra hidrokarbon sektörünün üretiminde ve fiyatlarında meydana gelen artışlar ön planda olmuştur. Öte yandan, 2011 yılında hükümetin değişmesi ve terör saldırıların artmasıyla birlikte dış ticarette düşüş yaşanmıştır. Ülkenin dış ticareti 2015 yılından itibaren açık vermeye başlamıştır. Nijer Deltasına yapılan terör saldırısı, artan askeri harcamaları, düşen petrol gelirleri ve yolsuzluk iddialarından dolayı ülkede kriz meydana gelmiştir. 2016 yılında ülkenin resesyon sürecine girmesi ve döviz gelirlerinde düşüş yaşanması ithalatı olumsuz yönde etkilemiştir. 2017 ve 2018 yılında petrol fiyatlarında yaşanan artışlar ve ihracatın toparlanmaya başlaması ile birlikte dış ticaret dengesi olumlu bir seyir izlemiştir.

Grafik 2: MINT Ülkelerinin Dış Borç ve Büyüme İstatistikleri
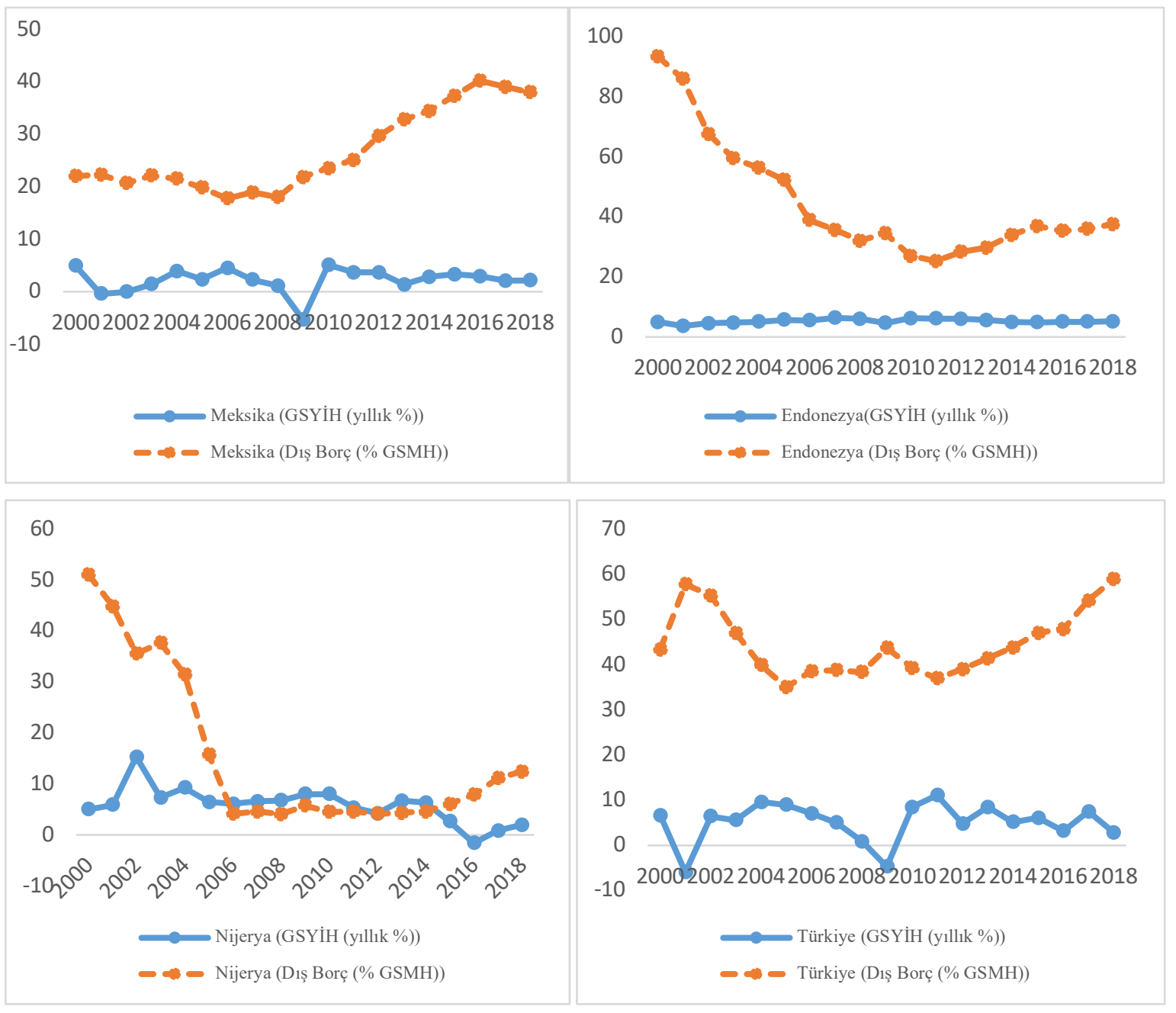

Kaynak: World Bank, (2020).

Grafik 2'de MINT ülkelerinin dış borç ve büyüme oranları gösterilmektedir. İlk olarak dünyanın 15. büyük ekonomisi olan Meksika'nın ekonomisi incelendiğinde Meksika'nın 2008 yılında yaşanan küresel finansal krizden önemli ölçüde etkilendiği görülmektedir. 2008 yılında yaşanan kriz, Meksika'da uyuşturucu kartellerin neden olduğu şiddet olayları ve ülkeden dünyaya yayılan H1N1 salgınından dolayı 2009 yılında resesyona girmiştir. 2008 yılında \%1,14 oranında büyüyen ülke ekonomisi 2009 yılında \%5,8 oranında küçülmüștür. Dış talepte meydana gelen azalmalar ve kamu harcamalarının azalmasından dolayı 2013 yılından itibaren $\% 2$ oranında büyüme 
kaydetmiştir. 2019 yılında yatırım ortamının belirsizliği, sıkı para politikası ve kamu harcamalarındaki azalmadan dolayı düşük büyüme söz konusu olmuştur. Grafik 2 incelediğinde dış borç ve büyüme arasında ters yönlü bir ilişkinin olduğunu söylemek genel itibariyle mümkündür.

Dünyanın 16. büyük ekonomisi olan Endonezya 1997 mali krizden bölgede önemli düzeyde etkilenen ülkedir. 2002 y1lından itibaren toparlanma sürecine giren Endonezya 2004 y1lında iktidara gelen hükümetin almış olduğu tedbirlerle $\% 6$ düzeyinde büyüme oranını yakalamıştır. 2008 küresel finansal kriz döneminde Endonezya ekonomisinin bütçe açığı çok yüksek rakamlara ulaşmış ve faiz oranları sabit tutulmaya çalışılmıştır. 2012 yılının dördüncü çeyreğinde düşük ihracat Endonezya ekonomisini özellikle büyüme düzeyini olumsuz yönde etkilemiştir. 2015 y1lında küresel finansal krizden sonra en düşük seviyesini yakalamış ve \%4,87 düzeyinde gerçekleşmiştir. 2018 yılda ABDÇin ticaret savaşının etkileri ve Cumhurbaşkanlığı seçimlerinden dolayı yatırım üzerinde yarattığı etkiye bağlı olarak büyümede artış yaşanmıştır. Endonezya merkez bankası 2019 yılında büyümeyi desteklemek için borçlanma maliyetlerini düşürerek agresif bir gevşeme yoluna girmiştir. Grafik 2 incelendiğinde dış borçların çok yüksek olduğu gözlenmektedir. Ayrıca dış borç ve büyüme arasında ters yönlü bir ilişkinin olduğunu söylemek mümkündür.

MINT ülke gurubunda yer alan Nijerya ise dünyanın 31. büyük ekonomisine sahiptir. Nijerya ekonomisi devlet ağırlıklı ve ihracatının neredeyse \%90'nını ham petrol üzerinden sağlamaktadır. Nijerya bugün dünyanın en yoksul ülkelerinden biridir ve üçte biri açlık sorunu ile karşı karşıya kalmaktadır. Ancak ülke kriz döneminde bile büyüme yaşamış ve 2016 yılına kadar büyümesini sürdürmüştür. 2006-2008 dönemlerinde yaşanan büyümenin kaynăğ petrol kaynaklı değildir aksine tarım, ulaşım, haberleşme ve hayvancılıktan kaynaklı olmuştur. 2016 yılında döviz gelirinde yaşanan düşüş ve ithalatın finansmanında yaşanan problemlerden dolayı ülke resesyon sürecine girmiş ve büyüme \%-1,61 düzeyinde gerçekleşmiştir. 2017 yllında hükümet öngördüğü bütçe gelirini sağlayamamış ve durgunluk 2017 yılının ikinci çeyreğinin sonuna kadar devam etmiştir. 2018 yılından itibaren sanayi ve hizmet üretiminde meydana gelen artışlar, petrol fiyatlarının artması ve döviz kurunda yaşanan toparlanmalar büyümeyi de olumlu yönde etkilemiştir. Grafik 2 incelendiğinde dış borçlar ve büyüme arasında herhangi bir etkinin olmadığını söylemek mümkündür.

Son olarak dünyanın 19. en büyük ekonomiye sahip olan Türkiye'nin büyüme ve dış ticaret verileri incelendiğinde 2000-2018 yılları arasında özellikle büyüme oranlarının sürekli dalgalandığı dikkat çekmektedir. 2001 yılında yaşanan likidite krizi sonrasında ekonomik büyüme \%-5,96 düzeyinde gerçekleşmiş ve krizin reel sektöre yansımasıyla birlikte işsizlik artmış, ülke yüksek enflasyon, yüksek kur ve yüksek faiz sorunlarıyla karşı karşıya kalmıştır. 2002 yılında AKP'nin yönetime gelmesiyle birlikte uygulamaya koymuş olduğu "güçlü ekonomiye geçiş programı" ile birlikte ekonomi toparlanmaya başlamıştır. 2008 yılında ABD kaynaklı mortgage küresel finansal krizden Türkiye'de etkilenmiş ve büyüme oranı 2001 krizinden sonra ilk defa eksilere düşmüş \%4,70 düzeyinde gerçekleşmiştir. 2008 yılında küresel ekonomide yaşanan yatırım ve tüketim harcamalarının azalması ve artan tasarruf eğiliminin etkisiyle iç talepte meydana gelen düşüşler Türkiye'nin GSYIHH büyüme oranlarının da düşmesine neden olmuş ve 2010 yılına kadar etkileri devam etmiştir. 2009 yılında dünyada yer alan finansal krizin piyasalarda yarattığ 1 dış kaynaklı güvensizlikler ve 2011 sonrasında Türkiye ekonomisinde ve siyasetinde yaşanan kırılganlıklar söz konusu yıllarda finansman imkânlarının kısıtlanmasına ve sermaye girişlerinin duraklamasına neden olmuştur. Bu dönemde gerek büyüme oranında yavaşlama gerekse dış borç gereksinimlerinde artış dikkati çekmektedir. 2016 ve 2017 yılında yaşanan ABD-Türkiye arasındaki vize krizi, Rahip Brunson olay1, S-400 müzakereleri ve darbe girişiminden dolayı büyümede düşüş yaşanmıştır. 2018 yılında özellikle kur artışlarının yarattığı enflasyon artışı yurtiçi talebin daralmasına yol açmasıyla birlikte özellikle sanayi kesimi olmak üzere bütün alanlarda üretimde gerileme olmuş ve büyümede de düşüşler yaşanmıştır. Grafik 4 incelendiğinde Türkiye'nin dış borçlarında meydana gelen artışın 
olduğu dönemlerde büyümenin düşük düzeylerde kaldığı görülmektedir. Buna göre dış borç ve ekonomik büyüme arasında Türkiye için ters yönlü bir ilişkinin olduğunu söylemek mümkündür.

\section{Sonuç}

Diș borçlanma ekonomik bir kavram olarak nitelendirilse de ülke açısından değerlendirildiğinde siyasi ve toplumsal ilişkileri önemli ölçüde etkilemektedir. Borç alan ülkeden ziyade borç veren ülke ya da ülkedeki finans kuruluşlarının yönlendirme çabaları borç alan ülkenin ulusal bağımsızlığında sorunlar oluşmasına neden olurken aynı zamanda makroekonomik politikaların uygulamasını da zorlaştırmaktadır. Buna rağmen ülkelerin dış borca yönelik talepte bulunmalarının nedenleri arasında iç tasarrufların yetersiz olması, ihtiyaç duyulan yatırımların yapılamaması, ihracat gelirlerinin düşük olması ve dolayısıyla dövizde yaşanan sıkıntılar yer almaktadır.

Uluslararası yatırım bankası olan Goldman Sachs Bank'ın Varlık Yönetim Başkanı Jim O'Neill 2001 yılında, dünyanın en büyük gelişmekte olan pazarlarını tanımlamak için "BRIC" terimini kullandığı bir rapor yayınlamıştır. BRIC; Brezilya, Rusya, Hindistan ve Çin Halk Cumhuriyeti'nin baş harflerinden oluşan bir terimdir. Güney Afrika Cumhuriyeti 2010 yılında BRIC topluluğuna katılmış ve söz konusu terim BRICS olarak güncellenmiştir. BRICS ülkelerinin farklı bir ekonomik grup olarak değerlendirilmesinde, Rusya'nın meta güdümlü bir ekonomisinin olması, Çin'in ihracat odaklı ekonomisinin olması, Hindistan'ın tüketici kaynaklı bir ekonomisinin olması, Brezilya'nın ekonomik yapıyı önemli düzeyde geliştirmesi ve Güney Afrika'nın hızla büyüyen bölgeyi temsil etmesi önemli rol oynamaktadır. Çalışmamızda BRICS ülkelerinin dış borç ve büyüme ilişkisi 2000-2018 verileriyle incelenmiştir. Bu kapsamda BRICS ülkelerinin verileri incelendiğinde genel olarak dış borçlarında artış olduğunda büyümede düşüş yaşandığı gözlemlenmiştir. BRICS ülkeleri arasında özellikle Çin ile yapılan ticaret önemli olmaktadır.

BRICS ülkeleri incelendiğinde özellikle 2008 küresel finansal kriz sürecinden ciddi boyutlarda etkilendiğini gözlemlemek mümkündür. Buna karşın 2000'li y1llardan itibaren büyüme verileri incelendiğinde ekonomilerinin hızla büyüdüğü ve küresel ekonomiyi etkileme gücüne sahip oldukları söylenebilir. Bu doğrultuda Brezilya'nın 2013 yılında hükümette yaşanan yolsuzlukların ortaya çıkması ve ulaşım ücretlerine zam yapılmasıyla birlikte resesyonist döneme girmiş ve 2016 yılında ulusal para birimi olan Real'in değer kaybetmesiyle birlikte ekonomideki olumsuz süreç devam etmiştir. 2017 yılında emtia fiyatlarındaki artış ve iç talepte toparlanma gibi nedenlerle birlikte Brezilya ekonomisinin toparlandığını söylemek mümkündür. Rusya'da 2014 yılında yaşanan jeopolitik sorunlar ve petrol fiyatlarının düşmesi gibi nedenlerle ekonomide olumsuzluklar yaşanmış ve neredeyse bu durum 3 y1l sürmüştür. 2017 y1lında dış küresel talepte yaşanan artışlarla birlikte Rusya ekonomisinde bir toparlanmanın olduğunu söylemek mümkündür. İlerleyen süreçte Çin'in rakibi olarak ön plana çıkmaya hazırlanan Hindistan 2016 yılında 500 ve 1000 rupilik banknotların piyasadan çekilmesine yönelik kararların alınması ve 2017 yılında vergi düzenlemelerinin yapılmasıyla yavaş bir büyüme sürecine girmiştir. Dünyanın 2. büyük ekonomisi olan Çin'in 2012 yılında \%7'lerde seyreden düşük büyüme oranı "yeni normal" olarak adlandırılmış ve bu seviyelerde devam etmiştir. 2018 yılında ABD ile yaşamış olduğu ticaret savaşları ve yüksek borçlardan dolayı son 29 yılın en düşük büyüme düzeyini sürdürmektedir. Son olarak Güney Afrika ise Çin'in en büyük ticaret ortakları arasında yer almaktadır. 2015 yılında yaşanan develüasyonlar, emtia fiyatlarındaki düşüşler ve borç sürdürülebilirliğinde yaşanan sorunlar olumsuz etkilemiştir. Genel olarak baktığımızda ülkelerin dış borçları arttıkça büyümelerinde düşüşler yaşandığı gözlemlenmektedir. 2020 yılında Çin'in Wuhan kentinde ortaya çıkan corona virüs ülkeleri ciddi boyutlarda etkilemiş ve bu durumun dış ticaretlerine, dış borçlarına ve büyüme oranlarına yansıyacağı beklenmektedir.

Dört ülke grubuna, yani Meksika, Endonezya, Nijerya ve Türkiye'ye atıfta bulunan MINT kısaltmas1, ilk olarak 2014 yılında Boston merkezli bir varlık yönetim şirketi olan Fidelity Investments tarafindan oluşturulmuştur. O'Neill'in BRICS terimini ortaya attığında bu guruba dâhil 
etmediği fakat bu kapsamda değerlendirdiği ülkelerin de olduğu söylenebilir. Meksika, Endonezya, Nijerya ve Türkiye'yi kapsayan bu ülkeler 2014 yılının başlangıcından itibaren "yükselen devler" olarak nitelendirilmiştir. Geleceğe yönelik ekonomik beklentileri parlak olan MINT ülkeleri, BRICS ülkelerinden sonra gelen ekonomik güç olarak faaliyet gösteren bir ülke gurubudur. MINT ülkelerinin ortak özelliklerinden birisi de hızlı büyüyen genç ve dinamik bir iş gücü kaynağına sahip olmasidir.

MINT ülkeleri de BRICS ülkelerinde olduğu gibi 2008 krizinden ciddi boyutlarda etkilenmiştir. Meksika 2008 krizi ile birlikte ülkede yaşanan H1N1 salgını ve uyuşturucu kartelleri ile birlikte 2009 yılında resesyonist sürece girmiştir. Dış talepte ve kamu harcamalarındaki düşüşlerle birlikte ekonomik büyüme düzeyi \%2 düzeylerinde kalmıştır. Küresel finansal krizden sonra 2012 y1lında da ihracatta meydana gelen düşüşlerle birlikte en düşük büyüme oranı yaşayan Endonezya 2018 yılında ABD ve Çin arasındaki ticari savaşlardan etkilenmiştir. İhracatının \%90'ını ham petrol üzerinden sağlayan Nijerya ise 2016 yılında döviz gelirlerinde yaşanan düşüş ve ithalatın finansmanında yaşanan sorunlarla birlikte resesyon sürecine girmiştir. Buna karşın 2018 yılında petrol fiyatlarının artması ve hizmet ile sanayi üretimindeki artışlar gibi olumlu seyirlerle birlikte büyümede de artı̧̧lar gözlenmiştir. Son olarak MINT grubunda yer alan Türkiye'de ise büyüme oranlarında dalgalanmalar söz konusudur. 2001 yılında yaşanan likidite krizi ve 2008 yılında ABD'de yaşanan mortgage krizleri ülkenin büyüme düzeyini olumsuz etkilemiştir. 2016 yılında ABD ile yaşanan vize krizi ve Rahip Brunson olayı ülkenin büyüme oranlarına da yansımıştır. MINT grubuna dâhil olan ülkelerin dış borç ve büyüme ilişkisi incelendiğinde genel olarak değerlendirilecek olursa ters yönlü bir ilişkinin söz konusu olduğu gözlenmektedir. MINT gurubu da BRICS ülkeleri gibi tüm dünyayı etkileyen corona virüsten de ciddi boyutlarda etkilenmesi beklenmektedir. $\mathrm{Bu}$ süreçte her ne kadar reform paketleri uygulansa da ülkelerin büyüme, ihracat, ithalat ve dış borçlar gibi birçok makroekonomik göstergelere olumsuz yansıması beklenmektedir.

Sonuç olarak BRICS ve MINT ülkelerinin almış oldukları borçları üretimin artışını sağlamaya yönelik, milli geliri arttırıcı ve ülkenin kalkınmasını sağlayabilecek verimli yatırımlarda kullanmalıdır. Eğer bunlar sağlanırsa ülkelerin kalkınması ve uzun vadede dış borçlarda düşüşün yaşanması muhtemel olmakla birlikte iç tasarruflarda artış meydana gelebilir.

\section{Kaynakça}

ATAUM. (2017). Değişen Ekonomik Roller: Euro’ya BRICS Tuğlası. Ankara Üniversitesi Avrupa Toplulukları Araştırma ve Uygulama Merkezi, Yı1:3, Sayı:36, (çevrimiçi), http://bultenler.ankara.edu.tr/dergiler/49/947/sayi947.pdf, Erişim Tarihi: 14.02.2020.

Avramovic, D., at al. (1964). Economic Growth and External Debt. United State of America (USA): The Johns Hopkins Press, pp:1-199.

Bal, H., Basher, S., Mamun, A. H. \& Akça, E. (2017). Export-led Growth Hypothesis in MINT Countries: A Panel Cointegration Analysis. International Conference on Eurasian Economies, 36-43.

Bilginoğlu, M. A. \& Aysu, A. (2008). Dış Borçların Büyüme Üzerine Etkisi: Türkiye Örneği. Erciyes Üniversitesi Iktisadi ve İdari Bilimler Fakültesi Dergisi, Say1: 31, ss:1-23.

Çöğürcü, İ. \& Çoban, O. (2011). Dış Borç Ekonomik Büyüme İlişkisi: Türkiye Örneği (1980-2009). KMÜ Sosyal ve Ekonomik Araştırmalar Dergisi 13(21), 133-149.

Diallo, B. (2009). External Debt and Financing of Economic Development in Guinea. JOBNAME: No Job Name PAGE: 1 SESS: 46 211-239

Durotoye, A. (2014). The MINT Countries as Emerging Economic Power Bloc: Prospects and Challenges. Developing Country Studies, Vol: 4, No: 15, www.iiste.org 
BRICS ve MINT Ülkelerinde Dış Borç İle Büyüme Arasındaki İlişkinin Değerlendirilmesi... 1695

Erataş, F. \& Nur, H. B. (2013). Dıı̧ Borç ve Ekonomik Büyüme İlişkisi: Yükselen Piyasa Ekonomileri Örneği. Marmara Üniversitesi I.I.I.B.F. Dergisi, XXXV(II), 207-230.

Ersungur, Ş. M., Boz, F. Ç. \& Çınar, Ö. (2017). Türkiye ile BRICS Ülkeleri Arasındaki Dış Ticaret İlişkileri Arasındaki İlişkileri: Girdi-Çıktı Yöntemi ile Bir Analiz. Business and Economics Research Journal,8(3), 395-412.

Eser, L. Y. \& Birinci, N. (2014). İç ve Dış Borç Tercihini Etkileyen Faktörler. Uluslararası Yönetim İktisat ve Issletme Dergisi, 10(23), 31-51.

Gryczka, M. (2018). MINT Countries As Possible Rising Stars in The Global EconomyBenchmarking With BRICS Countries. Acta Scientiarum Polonorum Oeconomia, 17(3), 2331.

Gladun, E. (2018). The BRICS: A Major Participant in the Multipolar World Order. 5 BRICS Law Journal, 5(1), 169-177.

Gül, E., Kamac1, A. \& Konya, S. (2012). Dış Borcun Büyüme Üzerine Etkileri: Orta Asya Cumhuriyetleri ve Türkiye Örneği. International Conference on Eurasian Economies, Session 2B: Büyüme ve Gelişme II, 169-174.

Hayaloğlu, P. (2015). MINT Ülkelerinde Demokrasi Ekonomik Büyümeyi Nas1l Etkilemektedir?. Uluslararası Ekonomi ve Yenilik Dergisi, 1(1), 17-29.

Hjertholm, P., Laursen, J. \& White, H. (1998). Foreign Aid and Development: Lesson of Experience and Directions for the Future. the Development Economics Research Group (DERG) at the Institute of Economics, University of Copenhagen, 1-62.

Jash, A. (2017). The Emerging Role of BRICS in The Changing World Oder. IndraStra Global, 611, DOI: https://doi.org/10.6084/m9.figshare.5143222.

Klein, T. M. (1994). External Debt Management An Introduction. Washington: Word Bank Tehnical Paper, $\quad$ No: 245, 1-229, (çevrimiçi), http://documents.worldbank.org/curated/en/510421468739200034/pdf/multi0page.pdf

Kamacı, A. (2016). Dış borçların Ekonomik Büyüme ve Enflasyon Üzerine Etkileri: Panel Eşbütünleşme ve Panel Nedensellik Analizi. International Journal of Cultural and Social Studies,2(Special Issue:1), 165-175.

Krugman, P. (1988). Financing vs. Forgiving a Debt Overhang. Journal of Development Economics, 29(3), 253-268.

Kokotovic, F. \& Peter, K. (2016). The MINT Countries: A Regression Analysis of The Selected Economic Features. International Journal of Management Science and Business Administration Volume 2(5), 21-31.

Köksoy, F. (2020). Eastern Mediterranean in the Context of Energy Relations of the European Union and the Russian Federation. Fulya Köksoy (Edt.), Global and Regional Powers: Relations, Problems and Issues in the 21st Century, Peterlang Publications.

Moreira, S. B. (2005). Evaluating The Impact of Foreign Aid on Economic Growth: A Cross-Country Study. Journal of Economic Development, 30(2), 25-49.

Mrorazan, P. et all. (2012). The Role of BRICS in The Developing World. European Parliament, Directorate General For External Policies of Union, (çevrimiçi), http://www.europarl.europa.eu/activities/committees/studies.do?language=EN, Erișim Tarihi: 16.05 .2018 
Nissanke, M. \& Ferrarın1, B. (2001). Debt Dynamics and Contingency Financing: Theoretical Reappraisal of the HIPC Initiative. WIDER Development Conference on Debt Relief, 1-44.

Nwannebuike, U. S., Ike, U. J. \& Onuka, O. I.(2016). External Debt and Economic Growth: The Nigeria Experience. European Journal of Accounting Auditing and Finance Research,4(2), $33-48$.

Oğuz, O. (2018). Cari İşlemler Dengesi ve Büyüme İlişkisi: BRICS Ülkeleri Üzerine Panel Eşbütünleşme Analizi. International Journal of Economic and Administrative Studies, 443455.

O’Neill, J. (2001). Building Better Global Economic BRICs. Goldman Sachs Global Economic Paper No. 66 .

Ossemane, R. P. (2007). The Meaning of External Debt Sustainability Indicators in Mozambique in a Context of High Predominance of Megaproject. Instituto de Estodos Sociais E Econqmicos, Conference Paper,42, 1-48.

Satoglu, E. B. (2017). "Emerging" Through Foreign Investment: Investment Development Path Estimation of "MINT" Economies. Advances In Economics and Business, 5(5), 256-264.

Senadza, B., Fiagbe, A. K. \& Quartey, P. (2017). The Effect of External Debt on Economic Growth in Sub-Saharan Africa. International Journal of Business and Economic Sciences April Research,11, (1), 61-72.

Sesan, A. (2013). The Upshot of External Debt on Economic Growth in West African Countries: A Panel Data Approach. MPRA, Paper No: 52555, https://mpra.ub.unimuenchen.de/52555/1/MPRA_paper_52555.pdf

Stefansson, O. I. N. (2010). The BRICs and International Relations: An Assessment Of The Potential Leaders in A Global Future, Oddur Ingi Nyborg Stefánsson, Haskoli Island, (çevrimiçi), https://skemman.is/bitstream/1946/4715/1/BAloka.pdf, Erişim Tarihi: 18.05.2018.

Thussu, D. (2015). BRICS: Building A NWICO 2.0?. DOC Research Institute, (çevrimiçi). http://westminsterresearch.wmin.ac.uk/19892/1/Digital\%20BRICS\%20Building.pdf, Erişim Tarihi: 16.05.2018.

Uysal, D., Özer, H. \& Mucuk, M. (2009). Dış Borçlanma ve Ekonomik Büyüme İlişkisi: Türkiye Örneği (1965-2007). Atatürk Üniversitesi İktisadi ve İdari Bilimler Dergisi, 23, (4), 161-178.

Yalçınkaya, Ö. \& Temelli, F. (2014). Ekonomik Büyüme İle Cari İşlemler Dengesi Arasındaki İlişki: BRICS ve MINT (1992-2013). Süleyman Demirel Üniversitesi İktisadi ve İdari Bilimler Fakültesi Dergisi, 19(4), 201-224.

Zhumakunıva, T. \& Kydyralieva, Z. (2017). Kırgizastan'da Dış Borçların Ekonomik Büyüme Üzerindeki Etkisi. International Conference on Eurasian Economies, 366-372.

World Bank, (2020), (çevrimiçi), https://databank.worldbank.org/source/world-developmentindicators/Type/TABLE/preview/on\#, Erişim Tarihi: 29.02.2020.

World Bank, (2020), Imports and Exports of Goods and Services, (çevrimiçi), https://databank.worldbank.org/home.aspx, Erişim Tarihi: 14.03.2020. 